\title{
On the Taxonomy of Snakes in the Genus Leptodeira, with an Emphasis on Costa Rican Species
}

\author{
César L. Barrio-Amorós
}

Doc Frog Expeditions \& CRWild, Uvita, Puntarenas, Costa Rica (cesarlba@yahoo.com)

\begin{abstract}
Considerable confusion surrounds the taxonomy of snakes in the genus Leptodeira, which contains 12 currently recognized species. Herein I review the genus and recognize 15 species based on previously published morphological and genetic data. Easily recognized traits can be used to identify Costa Rican species of Leptodeira, and taxonomic insights into all species in the L. annulata-septentrionalis complex are discussed. Photographs of all currently recognized species and subspecies are included.
\end{abstract}

W hile attempting to understand the taxonomy of cateyed snakes (genus Leptodeira) in Costa Rica, I was overwhelmed by confusing information from old and new data. Also, when encountering species of Leptodeira in several Latin American countries, my colleagues were frequently unable to identify them, often using names that were obsolete. While important morphological (Duellman 1958) and genetic (Mulcahy 2007; Daza et al. 2009) data are available, these have led to few taxonomic conclusions and the identification of many species remains unclear.

Leptodeira Fitzinger 1843 is a largely Nearctic and Neotropical genus that (as of February 2019) contained 12 currently recognized species (Uetz et al. 2018): L. annulata

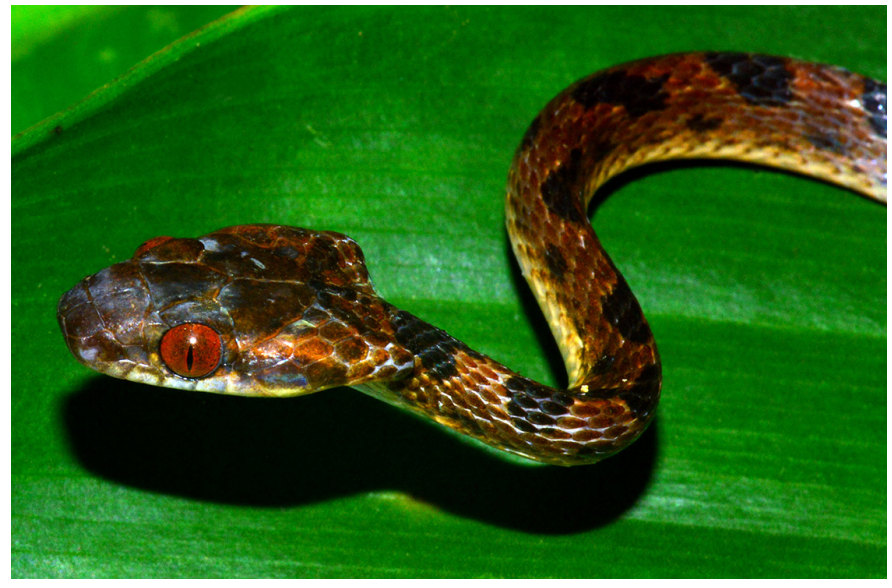

Leptodeira is derived from the Greek leptós (= narrow) and deiré (= neck) in reference to the obviously slender neck, which is most obvious when these snakes compress and widen the head during defensive displays. This snake is L. ornata from Bartola, Río San Juan, Nicaragua. Photograph by Milton Salazar.
(Linnaeus 1758), L. bakeri Ruthven 1836, L. frenata (Cope 1886), L. maculata (Hallowell 1861), L. nigrofasciata Günther 1868, L. polysticta (Günther 1895), L. punctata (Peters 1866), L. rhombifera Günther 1872, L. rubricata (Cope 1863), L. septentrionalis (Kennicott 1859), L. splendida Günther 1895, and L. uribei (Bautista and Smith 1992).

Based on hemipenial morphology, dentition, meristics, pattern, and geographic distribution, Duellman (1958) recognized four groups in the genus, which have been widely accepted. However, more recent genetic approaches (Mulcahy 2007; Daza et al. 2009; Mulcahy et al. 2011) revealed a completely different panorama, in which Duellman's L. annulata, L. maculata, and L. septentrionalis groups were paraphyletic and did not represent natural (monophyletic) entities. Nevertheless, pending a wide-ranging study of the genus, no important taxonomic changes were made, leaving the genus in chaos.

\section{The Costa Rican Situation}

In Costa Rica, currently available information is misleading. Two species (L. nigrofasciata and $L$. rubricata) are strikingly differentiable. Two other taxa appear have been listed recently under several names (Leptodeira annulata, L. rhombifera, $L$. septentrionalis, and L. polysticta). I herein present the correct names that should be applied to Costa Rican snakes in the genus Leptodeira. I am fully aware of the complex taxonomic status of many species (and subspecies) and clearly recognize that a comprehensive morphological and genetic revision of the genus remains necessary. However, the seminal work by Duellman (1958), still the principal morphological reference followed by many authors, combined with molecular 
data presented by Mulcahy (2007), Daza et al. (2009), and Mulcahy et al. (2011) provide abundant insights but remain open to further taxonomic action.

Savage (2002) and Solórzano (2004) established the identity and distribution of Costa Rican species of Leptodeira as follows: L. nigrofasciata occurs in the northwestern part of the country (and north into southern México); L. rubricata occupies the central and southern Pacific versant (barely reaching adjacent Panama); L. annulata is widely distributed from the northwest to the south, albeit rarer there, and also enters the Caribbean versant, where few records exist; and $L$. septentrionalis has the most extensive range, which includes both Caribbean and Pacific versants, but the species is less abundant in the northwest.

Attempting to determine how Costa Rican species differ remains a difficult undertaking, despite recent works by Savage (2002), Köhler (2003), and Solórzano (2004). Leptodeira nigrofasciata is the most distinctive species, readily distinguished by its characteristic pattern of alternating light and dark bands (not spots or blotches). Similarly, L. rubricata is easily recognizable by its coloration (the only reddish species with 57-67 dark bands/blotches). However, distinguishing $L$. rhombifera and L. ornata (until recently considered $L$. annulata and L. septentrionalis, respectively) is more challenging. Both (especially L. ornata) are exceedingly variable. Savage (2002) provided a key in which the most striking differences between the two species is a dorsal pattern, with that of the former having blotches usually outlined by lighter color and 151-181 ventrals, whereas the latter has dark dorsal blotches without light outlines and 186-211 ventrals. Köhler (2003) and Solórzano (2004) distinguished the two species using the number of ventrals $(<185$ in the former and $>185$ in the latter) plus other details too variable and confusing to be considered. However, counting ventrals is not always a possibility (e.g., when trying to identify a snake in nature or by means of a photograph) and the variation in patterns is so great that the light outlines of dorsal spots are not always evident in L. rhombifera, especially in areas where the two species are sympatric). Geographically, L. rhombifera occurs mainly on the Pacific side and particularly in the northwest, where it is associated with the dry forests of Alajuela, Guanacaste, and Puntarenas Provinces. I recently reviewed specimens of L. rhombifera at the Universidad de Costa Rica from both the Caribbean and southern Pacific sides, where this species primarily inhabits open and disturbed areas, whereas L. ornata always occurs in the rainforest. Leptodeira septentrionalis (herein as L. ornata) ranges along both Caribbean and Pacific versants at elevations to at least $1,800 \mathrm{~m}$ but is absent from the northwest where L. rhombifera is dominant. Kevin Venegas and I found an easy way to distinguish these species (in addition to the other characters mentioned). The postocular stripe is distinct in $L$. rhombifera and ill-defined in L. ornata; the iris of L. rhom-
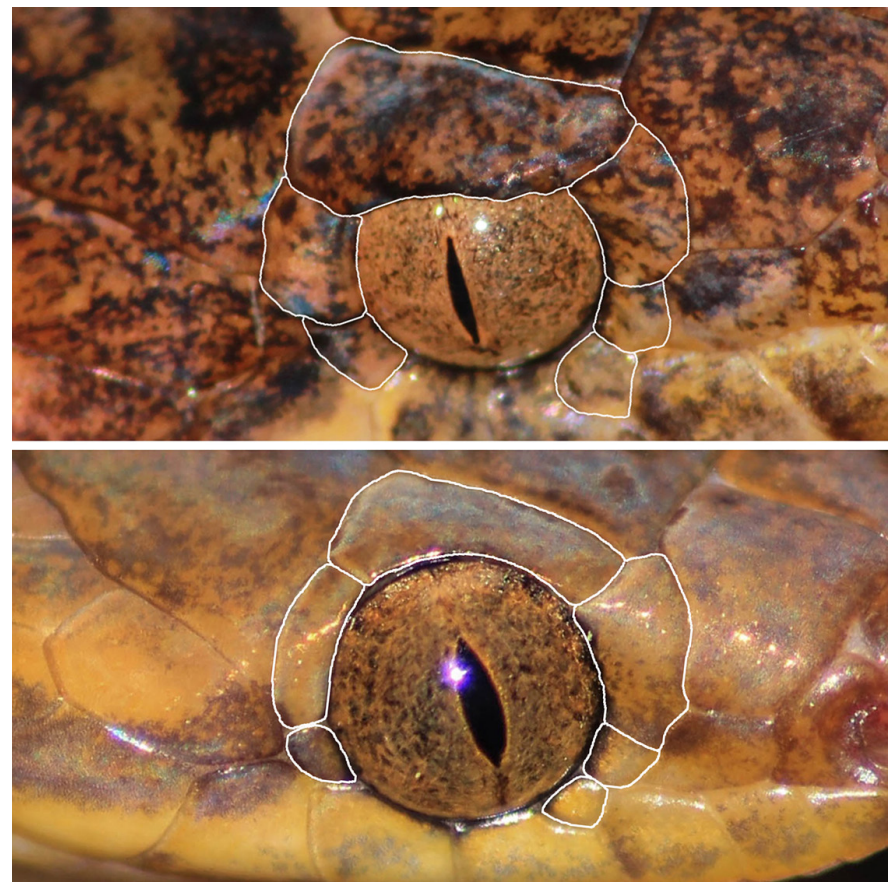

Fig. 1. Scales around eye of Leptodeira rhombifera (top) and L. ornata (bottom), showing the different meristic disposition. The most notable characters are the relative size of the eyes (always larger in L. ornata) and the shape of the postocular scale, square in L. rhombifera and elongate and quadrangular in L. ornata. Photographs by Kevin Venegas.

bifera is brown to grayish versus tan to bright orange in $L$. ornata (see the illustrations of L. ornata and L. rhombifera in the species accounts that follow), the size of the eye is always larger in L. ornata than in L. rhombifera; and the postocular scale is quadrangular and small in L. rhombifera, whereas it is rectangular but elongated in L. ornata (Fig. 1).

\section{Extant Species of Leptodeira}

The following accounts are for species of Leptodeira in the $L$. annulata-septentrionalis complex based on the morphological work of Duellman (1958), Savage (2002), and Solórzano (2004), and the genetic phylogenies of Mulcahy (2007), Daza et al. (2009), and Reyes-Velasco and Mulcahy (2010). Additionally, I provide accounts on the remaining species of Leptodeira in other taxonomic groups without entering the debate on the use of subspecies. In total, I recognize 15 species of Leptodeira as currently valid. A phylogenetic tree (Fig. 2 ), based primarily on the published work by Daza et al. (2009), shows the relationships among currently recognized species. Distributions by country are listed in Table 1, and Table 2 shows the number of species by country.

\section{The Leptodeira annulata-septentrionalis Complex}

Leptodeira septentrionalis (Kennicott 1859)

This species was described as Dipsas septentrionalis by Kennicott (1859), who designed three syntypes from 
Table 1. Distribution by countries for species of Leptodeira.

\begin{tabular}{|c|c|}
\hline Species & Distribution per countries \\
\hline L. annulata & $\begin{array}{l}\text { Pan-Amazonian: Colombia, Venezuela, Brazil, Bolivia, Peru, Ecuador, Guyana, Suriname French Guiana, } \\
\text { Paraguay, Argentina }\end{array}$ \\
\hline L. bakeri & Aruba, Venezuela (probably northern Colombia) \\
\hline L. frenata & Mexico and Guatemala \\
\hline L. maculata & Mexico \\
\hline L. nigrofasciata & Mexico, Guatemala, Honduras, El Salvador, Nicaragua, Costa Rica \\
\hline L. ornata & Panama, Costa Rica, Nicaragua, Honduras, Colombia, Ecuador; probably northwestern Venezuela \\
\hline L. polysticta & Mexico, Guatemala, Honduras, Nicaragua. \\
\hline L. septentrionalis & Mexico, United States of America \\
\hline L. splendida & Mexico \\
\hline L. uribei & Mexico \\
\hline
\end{tabular}

Table 2. Number of species in the genus Leptodeira by country.

\begin{tabular}{|c|c|}
\hline Countries & Species \\
\hline United States & L. septentrionalis (1) \\
\hline Mexico & $\begin{array}{l}\text { L. frenata, L. maculata, L. nigrofasciata, L. polysticta, L. punctata, L. rhombifera, L. septentrionalis, L. splendida, } \\
\text { L. uribei (9) }\end{array}$ \\
\hline Guatemala & L. frenata, L. nigrofasciata, L. polysticta, L. rhombifera (4) \\
\hline Honduras & L. rhombifera, L. polysticta, L. nigrofasciata (3) \\
\hline Nicaragua & L. nigrofasciata, L. rhombifera, L. polysticta (3) \\
\hline Costa Rica & L. nigrofasciata, L. ornata, L. rhombifera, L. rubricata (4) \\
\hline Panama & L. ornata, L. rhombifera (2) \\
\hline Colombia & L. annulata, L. ashmeadi, L. ornata (3) \\
\hline Brazil & L. annulata, L. ashmeadi (2) \\
\hline French Guiana & L. annulata (1) \\
\hline Suriname & L. annulata (1) \\
\hline Guyana & L. annulata (1) \\
\hline Venezuela & L. annulata, L. ashmeadi, L. bakeri (3) \\
\hline Argentina & L. annulata (1) \\
\hline Paraguay & L. annulata (1) \\
\hline
\end{tabular}




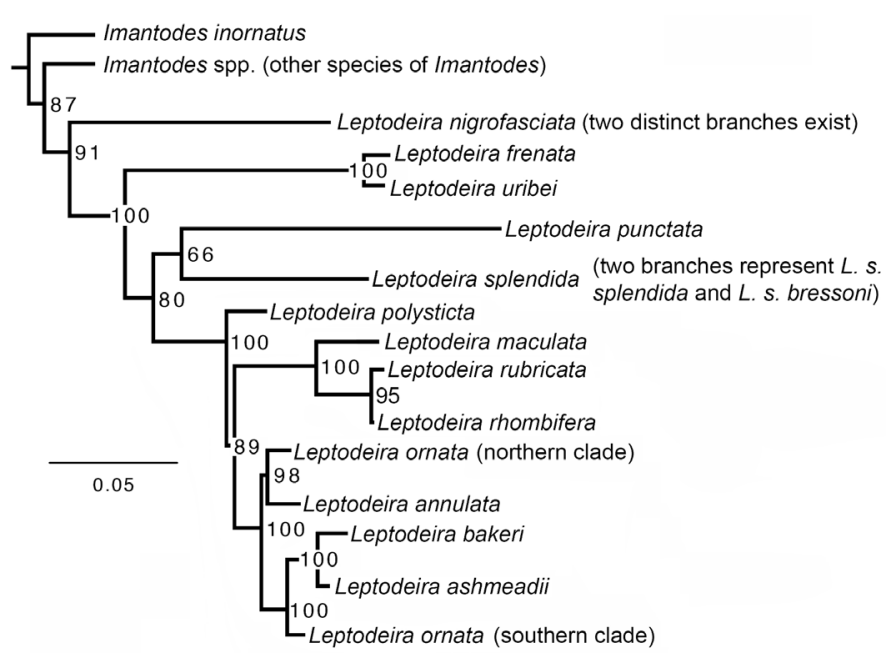

Fig. 2. Phylogenetic tree of Leptodeira based largely on Daza et al. (2009) and Reyes-Velasco and Mulcahy (2010).

Tamaulipas, Mexico, and one from Brownsville, Texas. Smith and Taylor (1950) restricted the type locality to Brownsville, using USNM 131739 as the lectotype.

Duellman (1958) considered the species polytypic, with four subspecies distributed from Texas through Mexico and

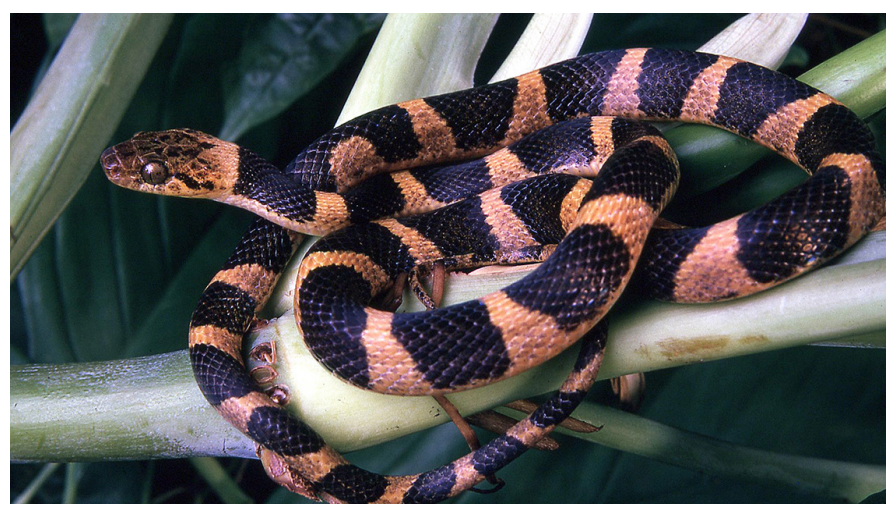

Fig. 3. Leptodeira septentrionalis from Tampico, Tamaulipas, Mexico. Photograph by Louis Porras.

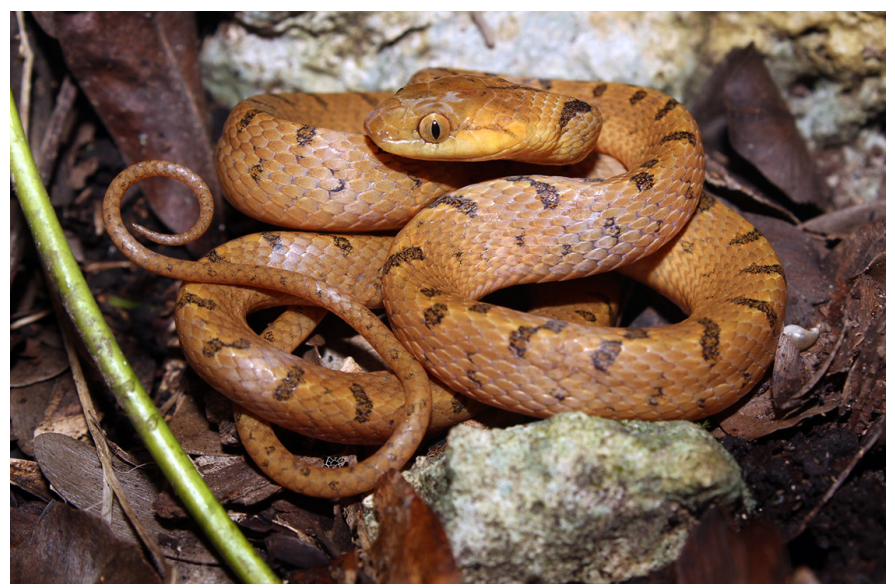

Fig. 5. Leptodeira polysticta from Chetumal, Quintana Roo, Mexico. Photograph by Pedro Nahuat.
Central America south to Peru along the western South American coast. The four subspecies recognized were $L$. $s$. septentrionalis (nominal form), L. s. polysticta Günther 1895 (type locality: Belize [= British Honduras]); L. s. ornata Bocourt 1875 (type locality: Isthmus of Darien, Panama); and L. s. larcorum Schmidt and Walker 1943 (type locality: Chiclin, Libertad, Peru).

In the phylogeny of Daza et al. (2009), snakes with the names polysticta and ornata are in different branches of the L. annulata-septentrionalis clade, rendering L. septentrionalis paraphyletic and necessitating the elevation of all valid names to species level to ensure monophyly. Unfortunately, L. septentrionalis (sensu stricto) and L. s. larcorum were not genetically tested. Leptodeira polysticta was considered a full species by Campbell (1998) and Uetz et al. (2018), but neither elevated the other two subspecies. Providentially, the pattern of $L$. septentrionalis is one of the most distinctive and should never be confused with any other Leptodeira. The ground color is tan to reddish tan with black wide and solid blotches or bands sometimes fused dorsally (Figs. $3 \& 4$ ).

Leptodeira septentrionalis (sensu stricto) is restricted to the Rio Grande embayment in southern Texas and northern Mexico (Pacific lowlands south to the Río Panuco and from

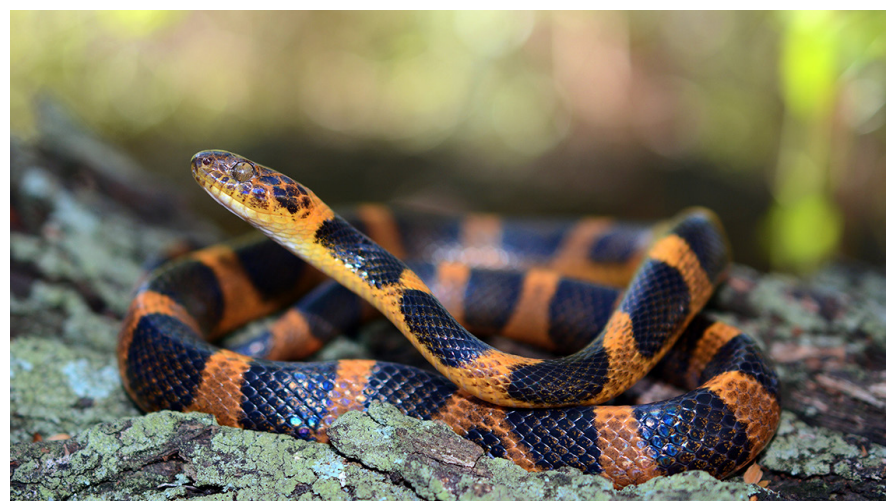

Fig. 4. Leptodeira septentrionalis from Willacy County, Texas, USA. Photograph by Clint Guadiana.

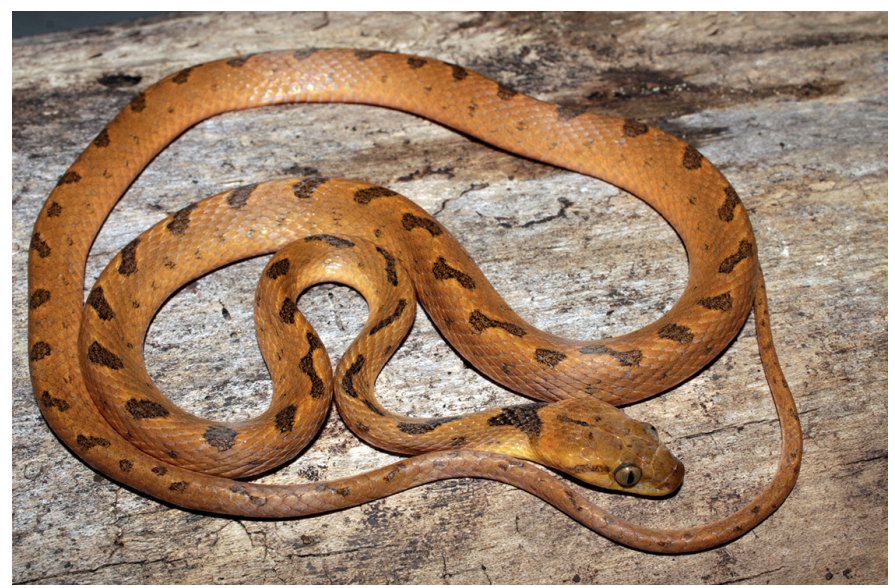

Fig. 6. Leptodeira polysticta from Punta Laguna, Quintana Roo, Mexico. Photograph by Pedro Nahuat. 
Tamaulipas south to Hidalgo). The state of Guerrero is not in the distribution of the species; consequently, "L. septentrionalis" in Mulcahy (2007) and Mulcahy et al. (2011) should be probably relegated to L. polysticta.

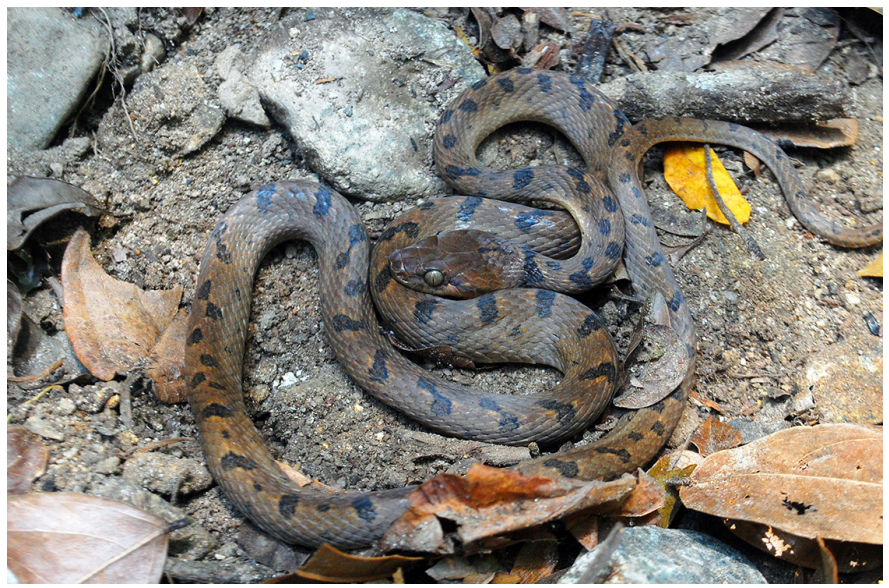

Fig. 7. Leptodeira polysticta from Pico Bonito, Honduras. Photograph by Josué Ramos Galdamez.

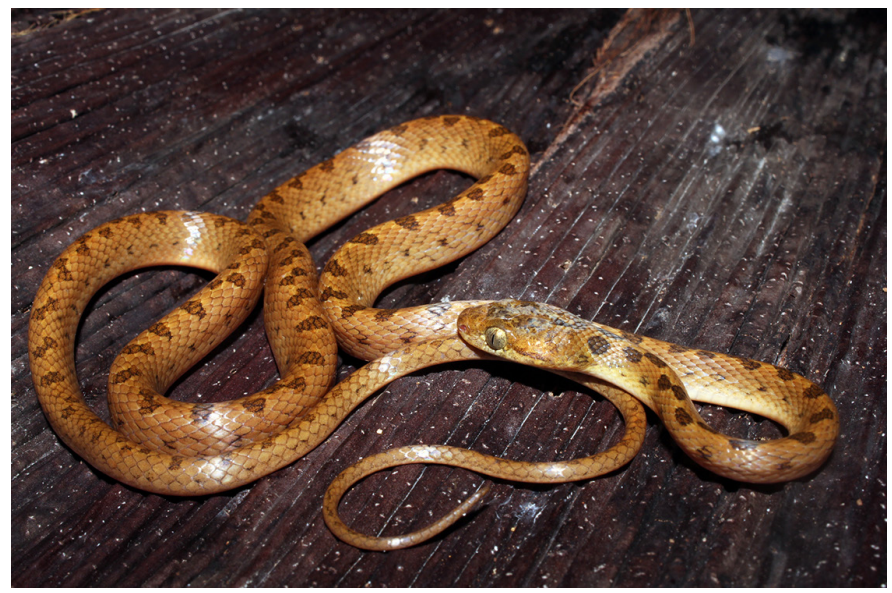

Fig. 8. Leptodeira polysticta from Nayarit, Mexico. Photograph by Pedro Nahuat.

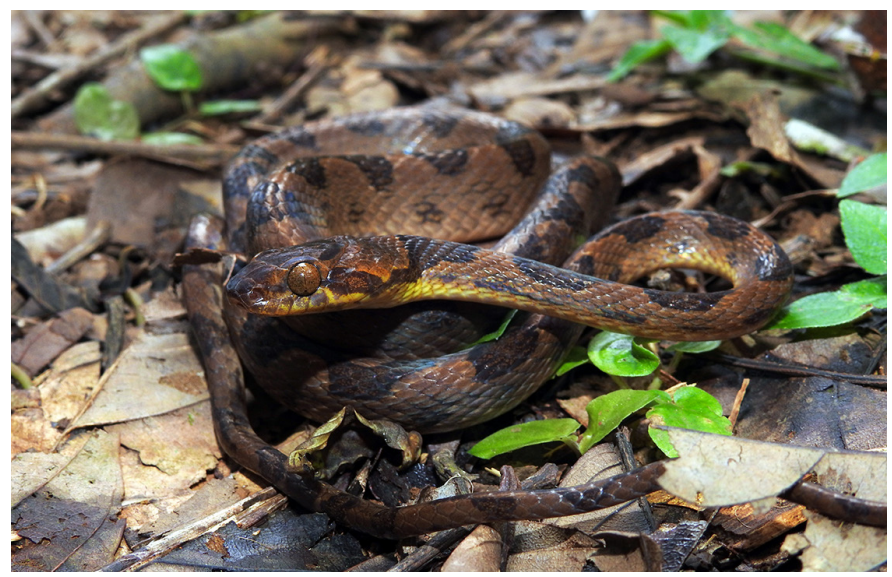

Fig. 10. Leptodeira ornata from the Isthmus of Darién, Panama. Photograph by Orlando Garcés.
Leptodeira polysticta (Günther 1895)

Originally described from Belize, this taxon has been recognized as a distinct species by Campbell (1998) and Uetz et al. (2018) but is still confused with L. septentrionalis (sensu lato). I examined living snakes and preserved specimens from Chetumal (Quintana Roo, Mexico) and observed striking differences in pattern that clearly distinguish them from the Costa Rican individuals (referred to L. ornata). For example, the Mexican snakes had much less reduced pattern (Figs. 5 \& 6). Leptodeira polysticta is distributed from southern Veracruz, the entire Yucatan Peninsula, Chiapas, and southern Oaxaca of Mexico south into Honduras (Fig. 7), El Salvador, and Nicaragua. Because the holotype of $L$. polysticta is from Belize (quite close to Chetumal), another clade of "L. polysticta" (Figs. $8 \&$ 9), probably deserving species status (see Daza et al. 2009), is distributed along the Pacific versant of Mexico, from Nayarit south to Guatemala and El Salvador. Leptodeira polysticta is not known from Costa Rica, although it could be present in some northern areas of the country.

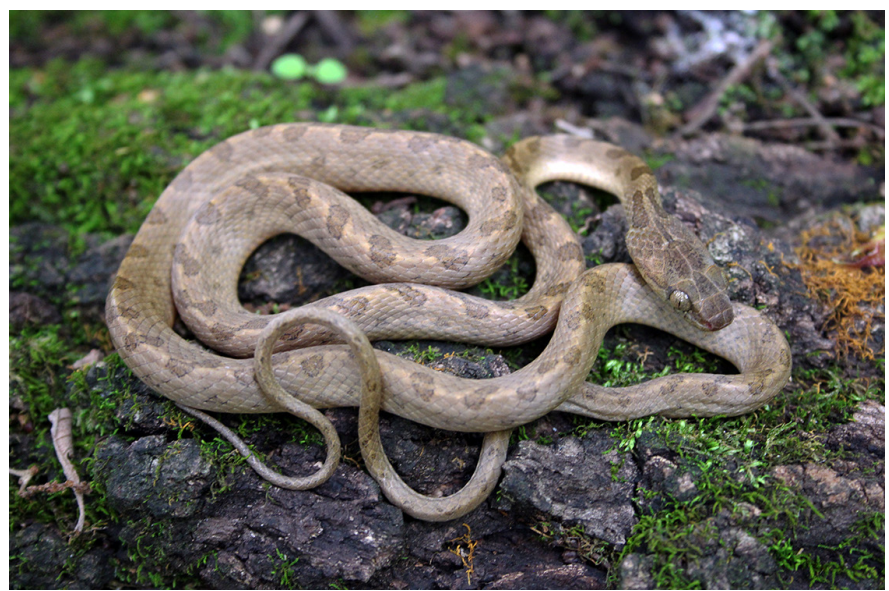

Fig. 9. Leptodeira polysticta. from Santa Cruz de Miramar, Nayarit, Mexico. Photograph by Iván Ahumada Carrillo.

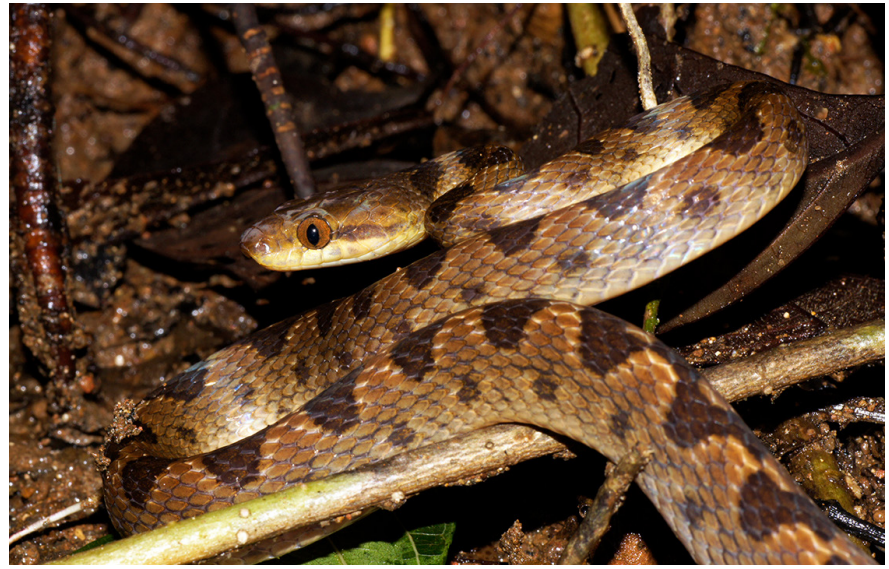

Fig. 11. Leptodeira ornata from the Península de Osa, Puntarenas, Costa Rica. Photograph by César L. Barrio-Amorós. 


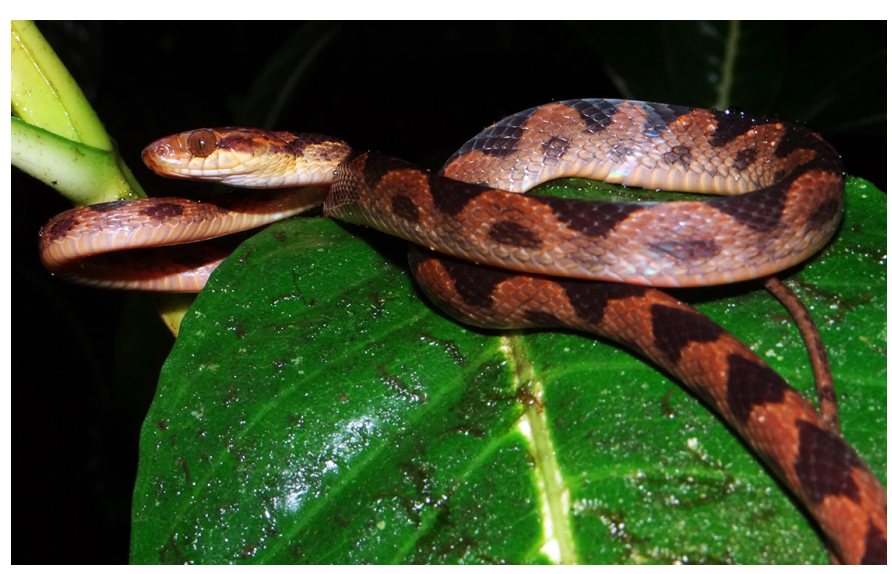

Fig. 12. Leptodeira ornata from the Esquinas Lodge, Golfito, Puntarenas, Costa Rica. Photograph by César L. Barrio-Amorós.

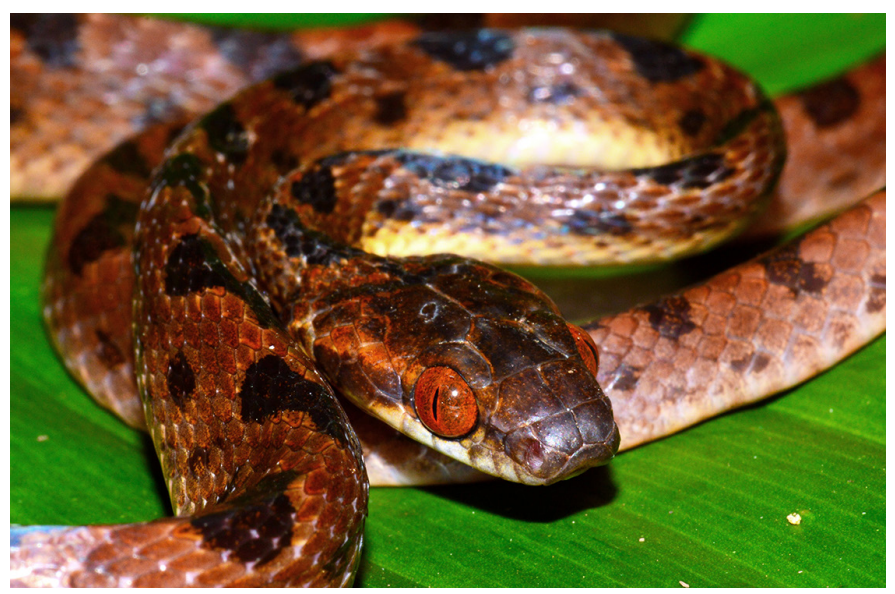

Fig. 14. Leptodeira ornata from Bartola, Río San Juan, Nicaragua. Photograph by Milton Salazar.

Leptodeira ornata Bocourt 1884 nov. comb.

Described originally from the Isthmus of Darién in Panama, this name refers to what was previously called " $L$. septentrionalis" in Costa Rica and Panama (and probably northwestern Colombia). So, all "L. septentrionalis" in Savage (2002), Köhler (2003), and Solorzano (2004) should now be referred to $L$. ornata. This species ranges from the type locality (Fig. 10) westward through Panama to Costa Rica along both versants (Figs. 11, 12, 13); where the range extends into Colombia is not clear. On the Caribbean versant, it extends into the Nicaraguan lowlands (Fig. 14) and reaches eastern Honduras (Fig. 15). On the Pacific versant, it ranges from Panama west and north to the Río Tárcoles (a natural barrier that separates humid rainforest to the southeast from the dry forest to the northwest). In that area, two other species of Leptodeira (L. nigrofasciata and L. rhombifera) occupy the niche usually associated with $L$. ornata.

Leptodeira ornata, as currently recognized, is not monophyletic and comprises two clades that are not closely related but are phenotypically very similar (e.g., see an individual from Colombia's Magdalena River Valley (Fig. 16). The

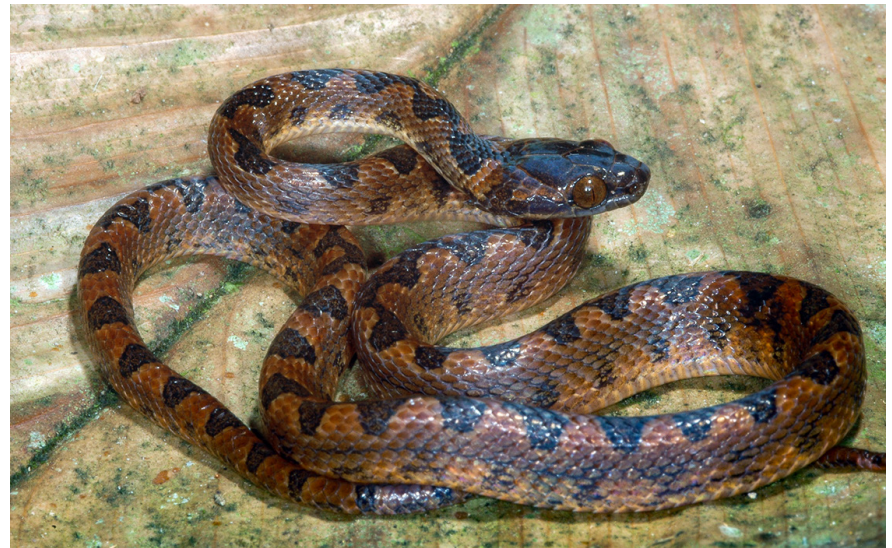

Fig. 13. Leptodeira ornata from Rara Avis, Heredia, Costa Rica. Photograph by Twan Leenders.

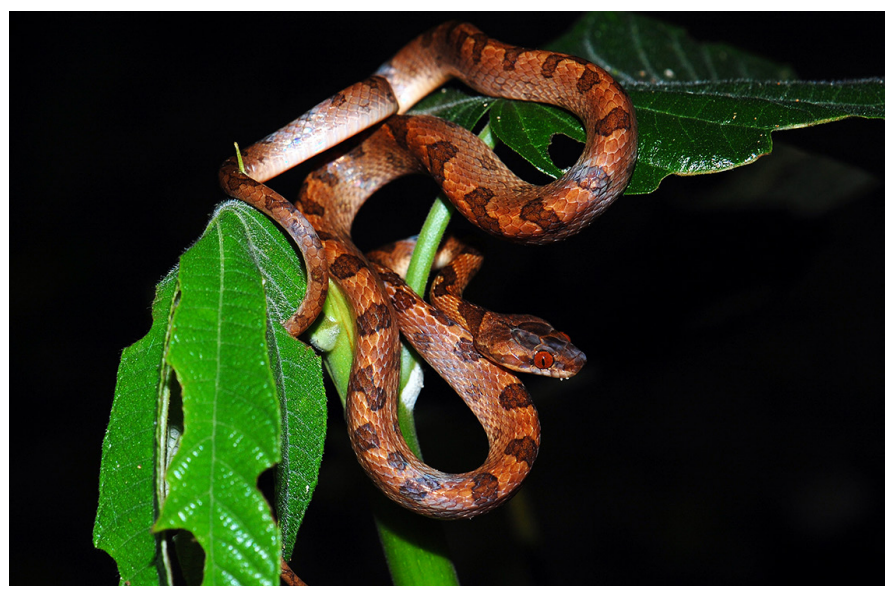

Fig. 15. Leptodeira ornata from Río Plátano, Honduras. Photograph by Josué Ramos.

Galería Bioweb Ecuador (https://bioweb.bio/galeria/Fotos/ Leptodeira\%20septentrionalis/Registros\%20fotográficos) also illustrates examples from central and northwestern Ecuador that are very similar to snakes of the northern clade of L. ornata. Although L. ornata (sensu stricto) from Costa

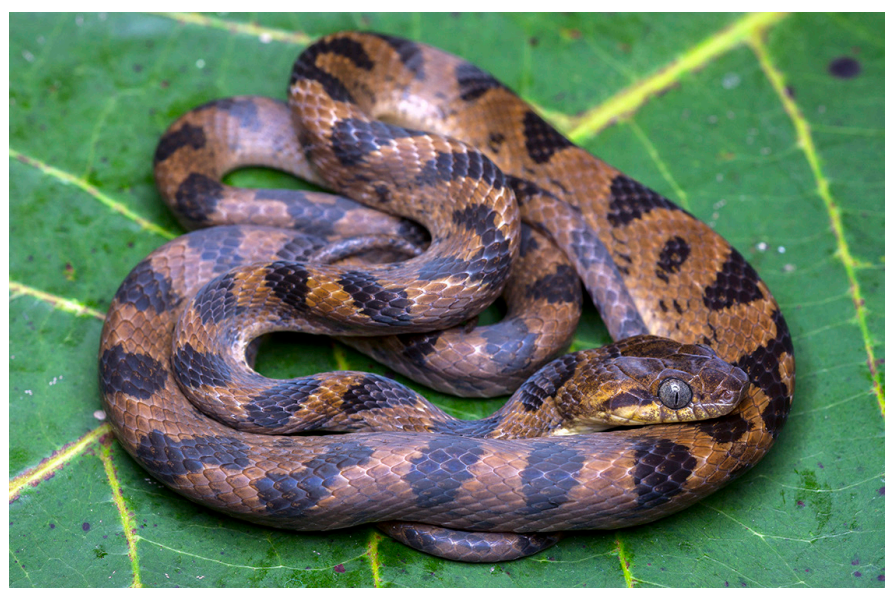

Fig. 16. Leptodeira ornata from the Valle Medio del Río Magdalena, Colombia. Photograph by Elson Meneses Pelayo. 
Rica and Panama is genetically closer to L. annulata from Amazonia, the southern clade from the Pacific versant of Colombia, the Magdalena and Cauca Valleys, and northern Ecuador are closer to L. ashmeadi and L. bakeri from northern South America. This means that southern "L. ornata" is a species awaiting formal description. No clear geographic barrier separates the two clades of $L$. ornata.

Leptodeira larcorum Schmidt and Walker 1943 nov. comb. This taxon was initially described from a semi-arid region near Chiclin in northwestern Peru, a very different habitat than the humid rainforest typical of L. ornata (sensu stricto) and the undescribed species of the southern clade of $L$. ornata.

Mulcahy (2007) and Daza et al. (2009) did not include L. larcorum in their studies; consequently, whether the name represents a valid taxon has not been confirmed by genetic analyses. However, this name could be applied to a form of Leptodeira of currently unknown affinities from northwestern Peru and southwestern Ecuador. I have no doubt that $L$.

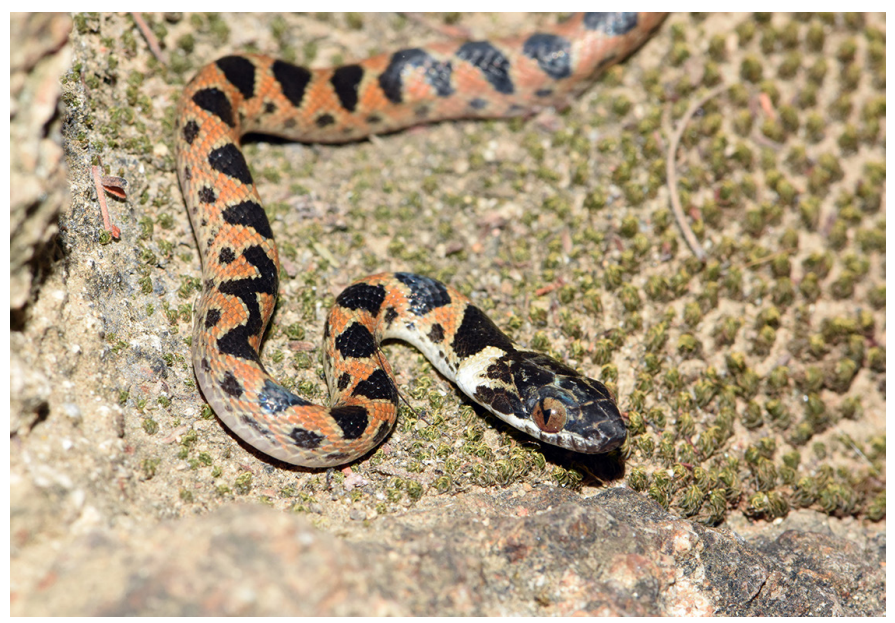

Fig. 17. Leptodeira larcorum from Bramaderos, Loja, Ecuador. Photograph by Sebastián Valverde.

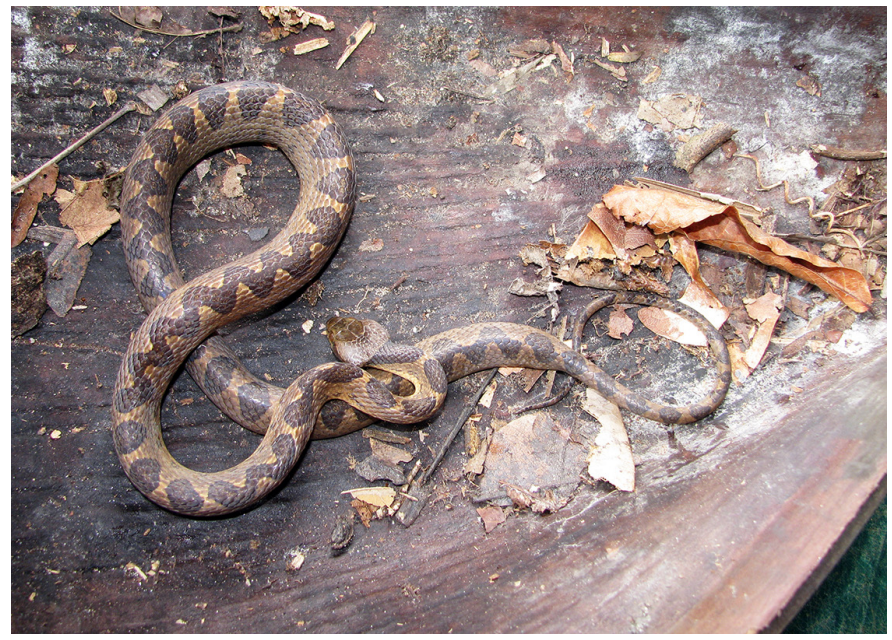

Fig. 19. Leptodeira annulata from Tocantins, Brazil. Photograph by Fabio Maffei. larcorum deserves specific status, as it inhabits a completely different habitat that is separated from that occupied by the southern L. ornata clade by an extremely arid environment. The pattern also is distinctive (Figs. $17 \& 18$ ).

Schmidt and Walker (1943), Duellman (1958), and Koch et al. (2018) assigned Leptodeira from the valley of the Marañon River, which is part of the Amazon Basin, to L. "s." larcorum. Biogeography alone suggests that this identification demands more attention since species in Amazonia do not generally range into areas west of the Andes.

\section{Leptodeira annulata (Linnaeus 1758)}

Clarifying the "L. septentrionalis" situation makes it easier to understand the remaining taxa. Duellman (1958) recognized five subspecies of $L$. annulata (L. a. annulata, $L$. a. cussiliris, L. a. rhombifera, L. a. ashmeadi, and L. a. pulchriceps), three of which have been elevated to species status. Duellman (1958) restricted the type locality of the nominal form, originally described from "America," to the lower Rio Amazon, Pará,

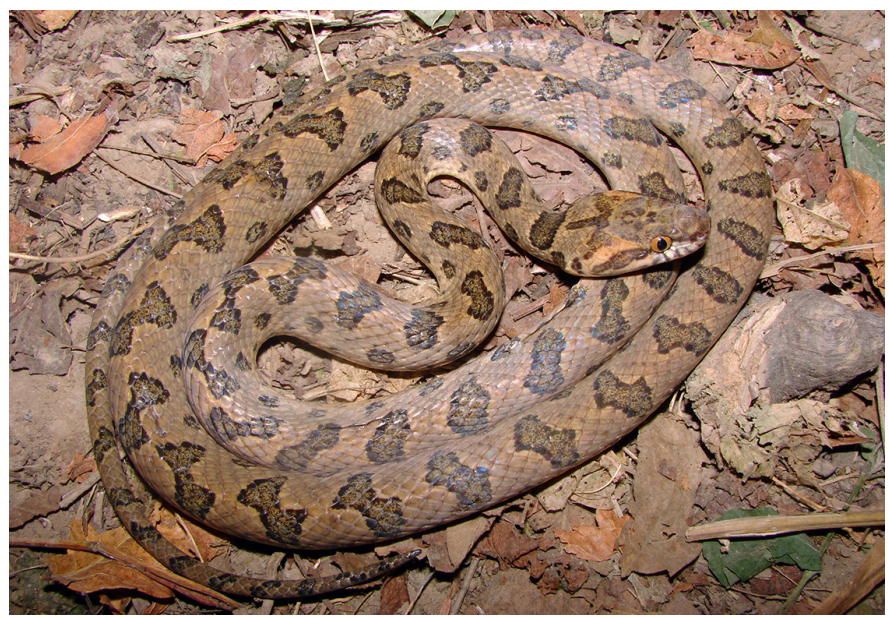

Fig. 18. Leptodeira larcorum from Piura, Peru. Photograph by P. Venegas

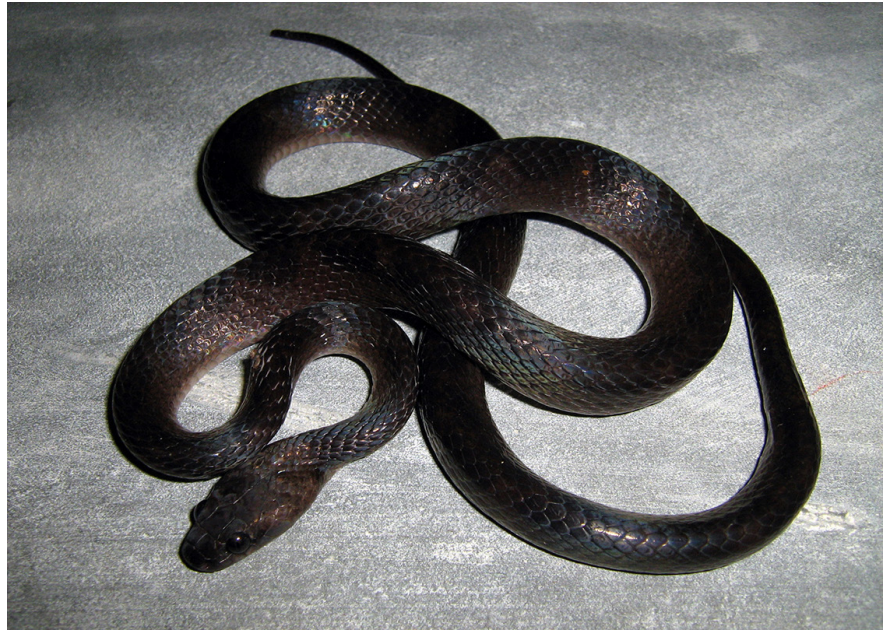

Fig 20. Leptodeira annulata from Acre, Brazil. Photograph by Saymon Albuquerque. 
Brazil. Its range is basically pan-Amazonian as it is distributed throughout the Amazon Basin of Brazil (Figs. 19, 20, 21, 22), Ecuador (Figs. $23 \& 24$ ), Colombia, Peru, southern Venezuela, and the Guianas as well as the Mata Atlantica of Brazil (Fig. 25). The striking diversity in patterns across the range of this taxon almost certainly reflects genetic diversity; if so, this name represents a species complex. Particularly nota-

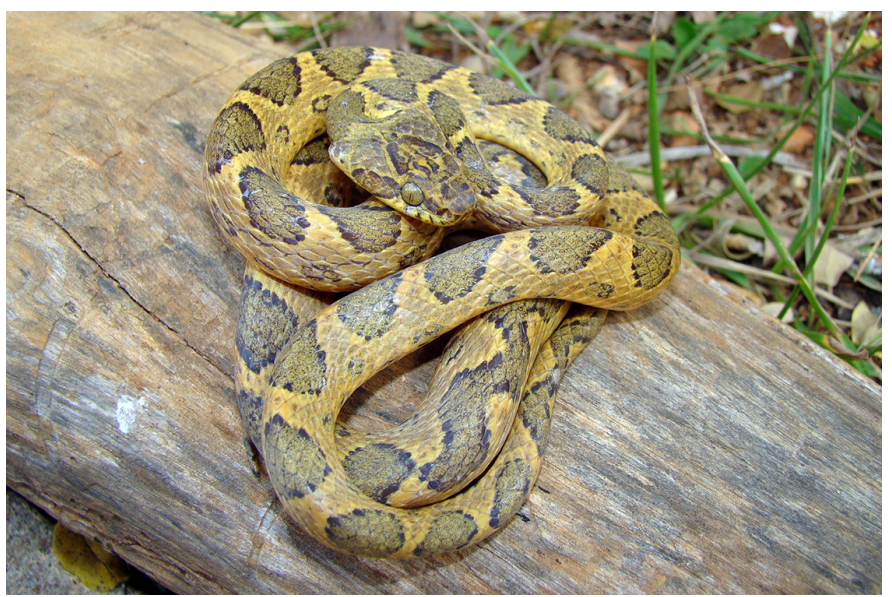

Fig 21. Leptodeira annulata from Brasilia, Federal District, Brazil. Photograph by Marco Antonio de Freitas.

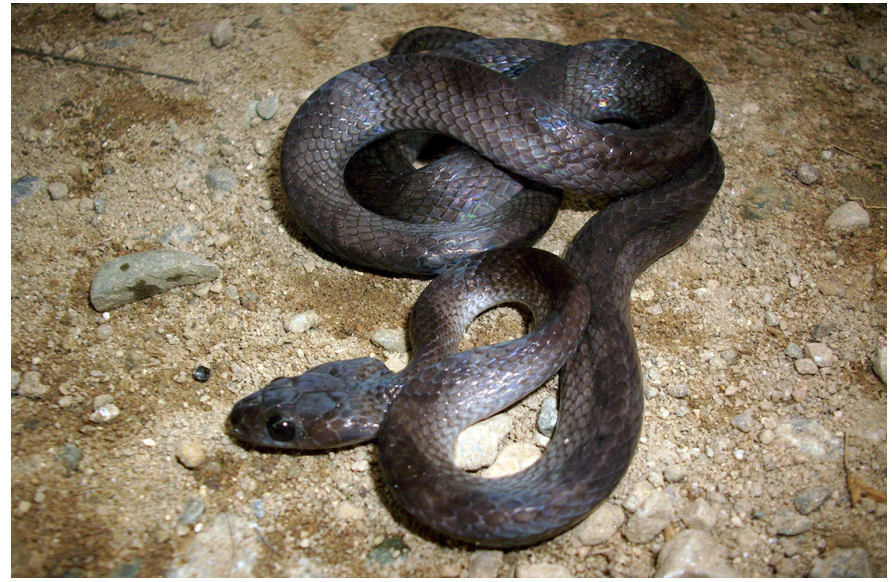

Fig 23. Leptodeira annulata from Zamora, Ecuador. Photograph by Sebastián Valverde.

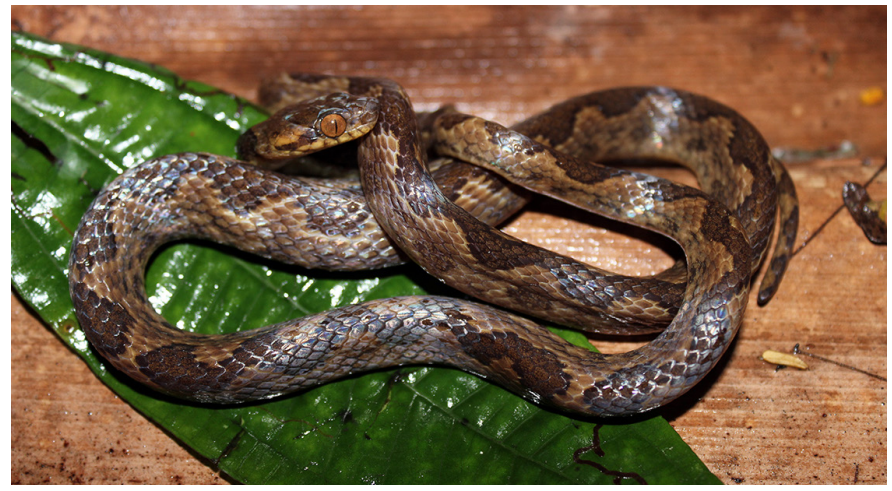

Fig 25. Leptodeira annulata from Bahía, Brazil. Photograph by Omar Machado. ble are the melanistic snakes from the Upper Amazon, one in the state of Acre, Brazil (Fig. 20) and the other in Zamora, Ecuador (Fig, 24).

The type locality of $L$. a. pulchriceps is Bodoquena, Mato Grosso, Brazil. This taxon (Fig. 26) has not been tested genetically and might or might not be valid. However, due to the lack of evidence to the contrary and the considerable variation

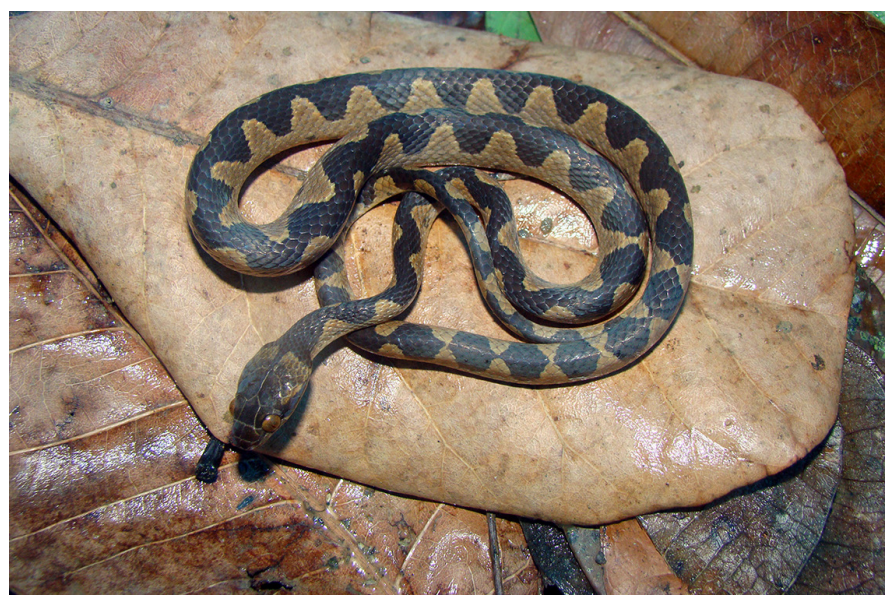

Fig 22. Leptodeira annulata from Centro Novo do Maranhao, Maranhao, Brazil. Photograph by Marco Antonio de Freitas.

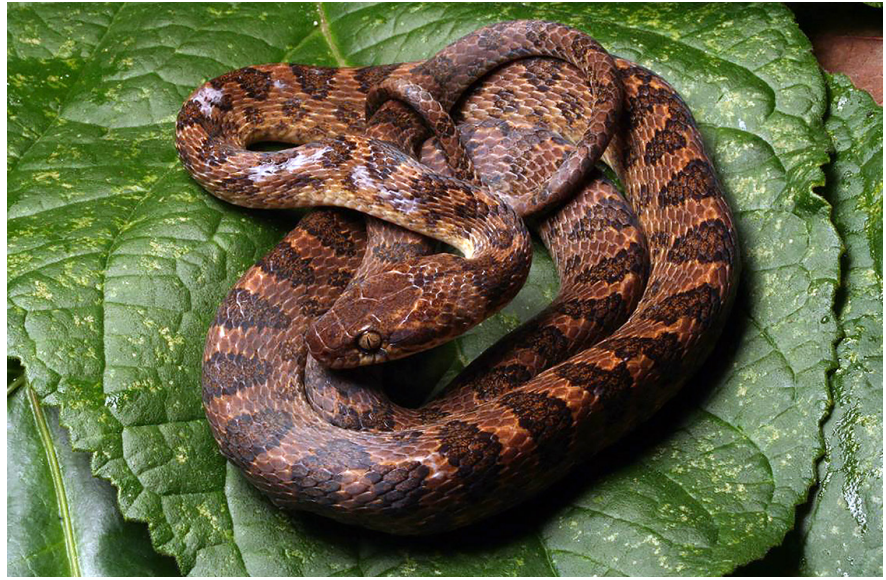

Fig 24. Leptodeira annulata from Yasuní, Ecuador. Photograph by David Salazar.

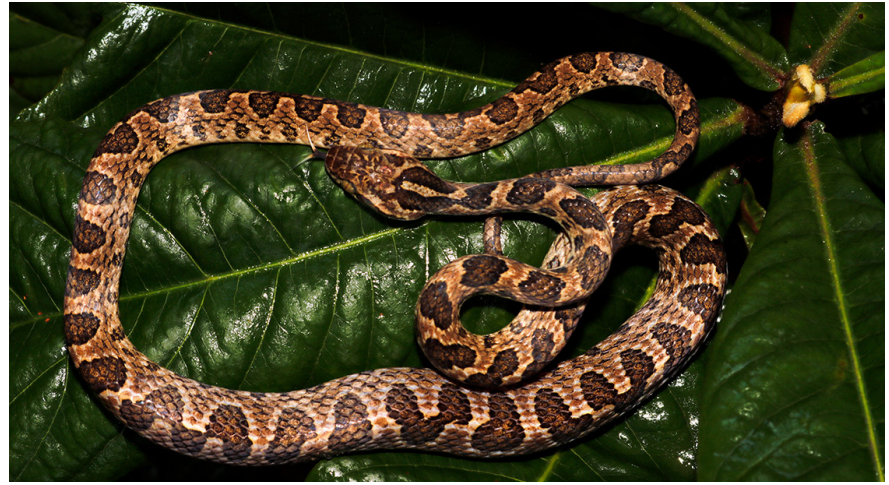

Fig 26. Leptodeira annulata from Bajo Chaco, Paraguay (previously referred to L. a. pulchriceps). Photograph by Danilo Krause. 


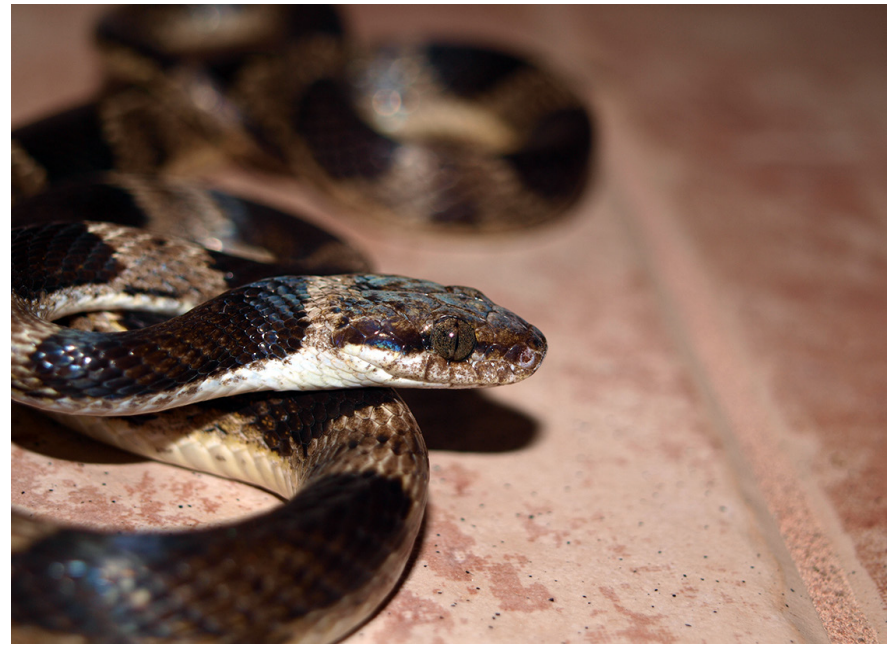

Fig 27. Leptodeira bakeri from Aruba. Photograph by Ton Dubislav.

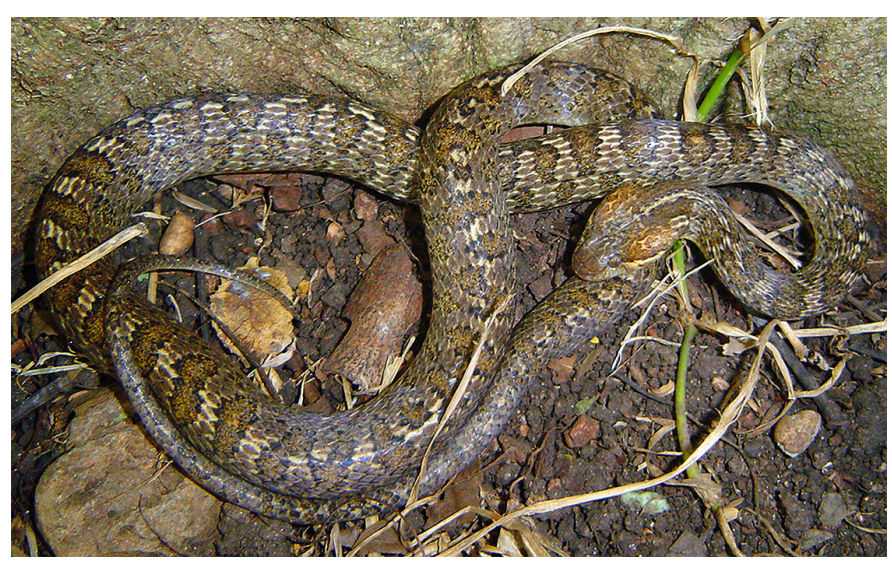

Fig 29. Leptodeira ashmeadi from Barquisimeto, Lara, Venezuela. Photograph by César L. Barrio-Amorós.

of L. annulata (e.g., Duellman 1958; Schrocchi 1980), L. a. pulchriceps probably is a junior synonym of $L$. annulata.

\section{Leptodeira bakeri Ruthven 1836}

This species was described by Ruthven (1936) from Aruba (Fig. 27), formerly part of the Dutch Antilles, and was considered endemic to the island until Mijares-Urrútia et al. (1995) reported it from Falcón State, Venezuela. In Venezuela (Natera-Mumaw et al. 2015), this species currently is known from the states of Falcón, Trujillo, and Zulia (Fig. 28). Described as a distinct species, it has consistently been regarded as such.

Leptodeira ashmeadi (Hallowell 1845) nov. comb.

This taxon was described originally from "the Republic of Colombia, within two hundred miles of Caracas" (now in Venezuela). All of the species mentioned by Hallowell (1845) are from the northern Cordillera de la Costa, but habitats within 200 miles $(322 \mathrm{~km})$ of Caracas include dry to very dry conditions that could be inhabited by $L$. ashmeadi but not

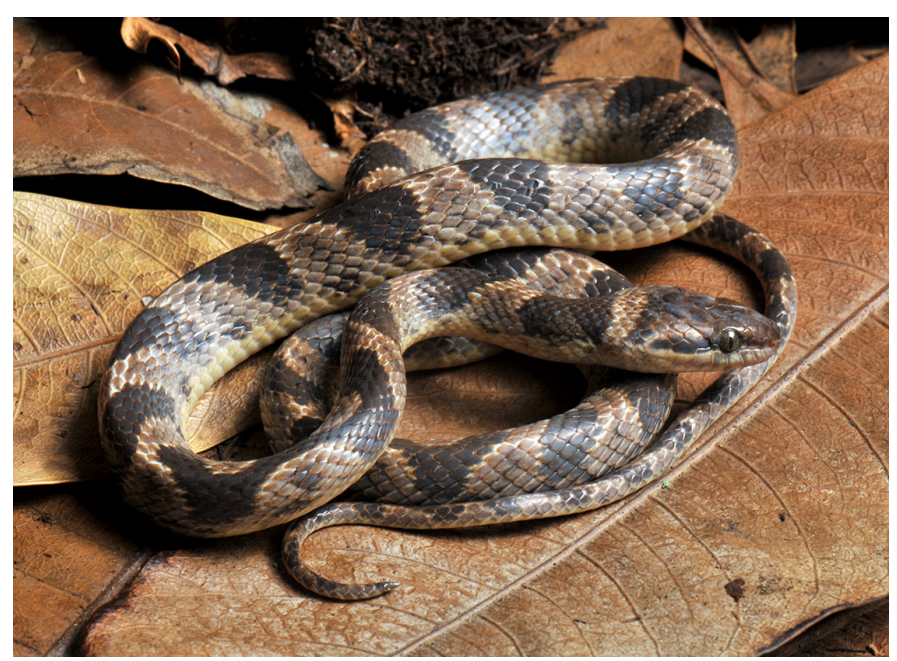

Fig 28. Leptodeira bakeri from the Jardín Botánico de Maracaibo, Zulia, Venezuela. Photograph by Luis Alejandro Rodríguez.

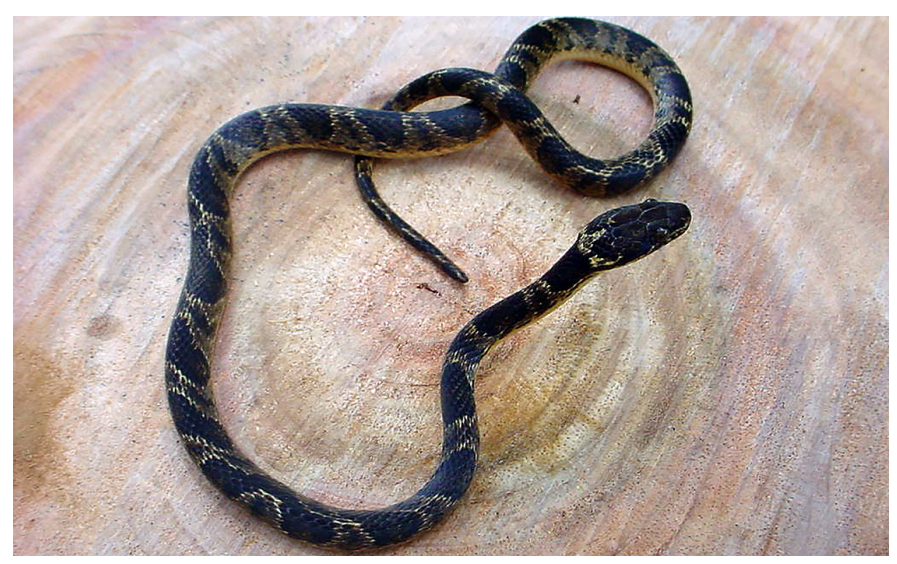

Fig 30. Leptodeira ashmeadi from Perijá, Ciénaga, Zulia, Venezuela. Photograph by Fernando Rojas-Runjaic.

by other snakes listed by Hallowell (1945). Duellman (1958) restricted the type locality to the vicinity of Caracas.

The northern South American forms of Leptodeira (from Venezuela, northern Colombia, Trinidad, and northern Brazil) differ from typical $L$. annulata somewhat in pattern (Natera-Mumaw et al. 2015) but also genetically. Daza et al. (2009) separated $L$. annulata from $L$. ashmeadi, which is nested with $L$. bakeri, which in turn is nested with $L$. ornata (southern clade), collectively forming a northern South American clade. The variation in pattern and shape seen in northern Venezuelan snakes (Figs. 29, 30, 31, 32) indicates that further morphological and genetic studies need to be pursued. Pérez-Santos (1999) considered the possibility that L. ashmeadi and L. rhombifera intergrade in Panamá, but this should be corroborated.

\section{Leptodeira rubricata (Cope 1863)}

This species, originally described from Boca Mala (Puntarenas) in Costa Rica, has one of the most strikingly different patterns (Fig. 33) of any Central American Leptodeira. Its coloration is 


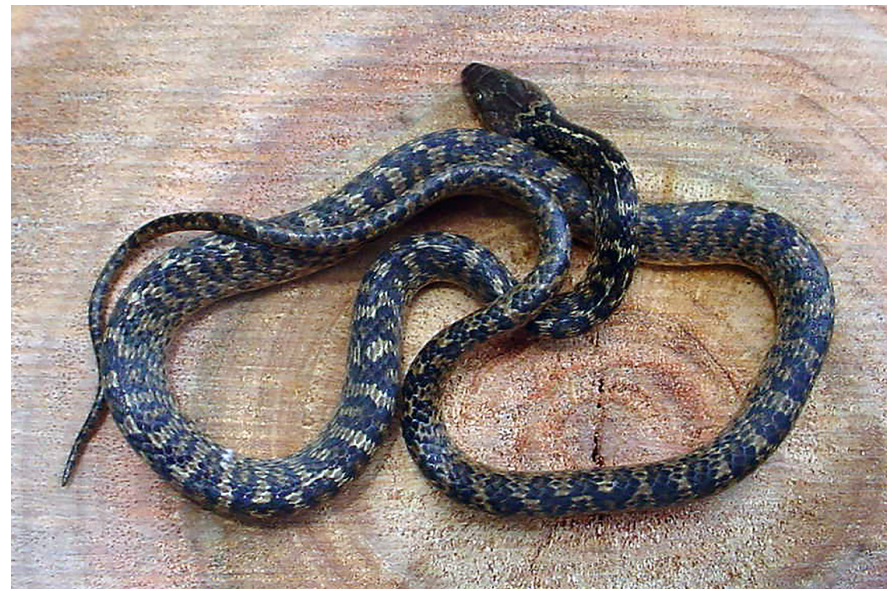

Fig 31. Leptodeira ashmeadi from Río Perijá, Zulia, Venezuela. Photograph by Fernando Rojas-Runjaic.

quite distinct from that of sympatric $L$. ornata and $L$. rhombifera. Nevertheless, Duellman (1958) synonymized it with $L$. annulata (currently L. rhombifera) and Savage (2002) resurrected it correctly but without much explanation. Daza et al. (2009) demonstrated that L. rubricata was nested basally with L. rhombifera, which could be argued to support synonymy.

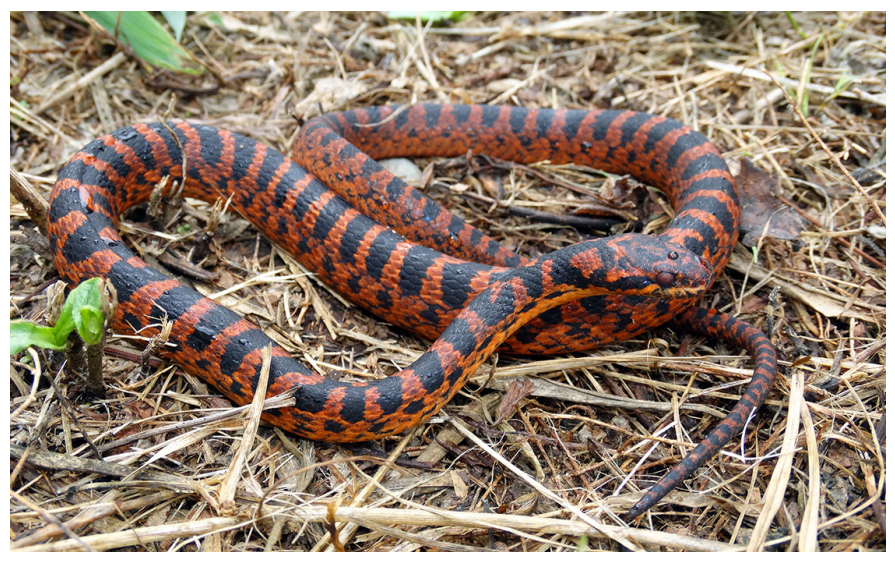

Fig 33. Leptodeira rubricata from Uvita, Puntarenas, Costa Rica. Photograph by César L. Barrio-Amorós.

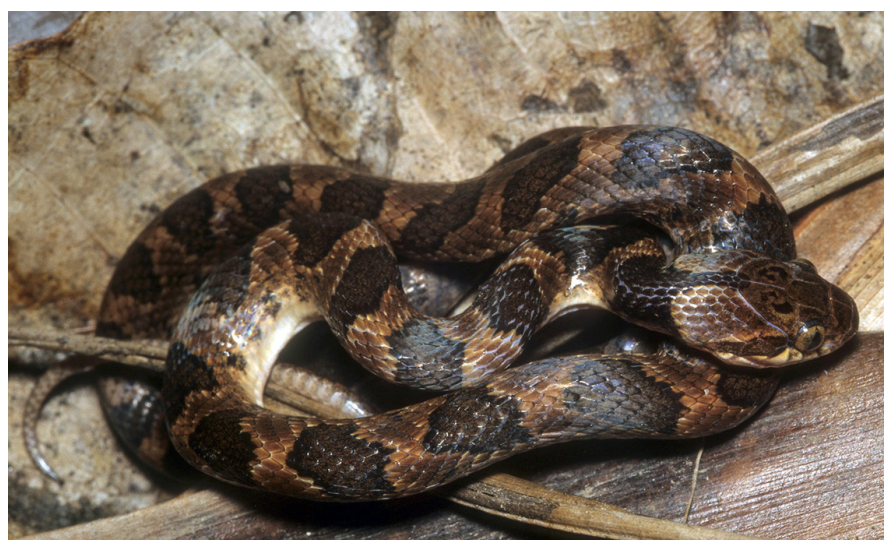

Fig 34. Leptodeira rhombifera from El Salvador. Photograph by Twan Leenders.

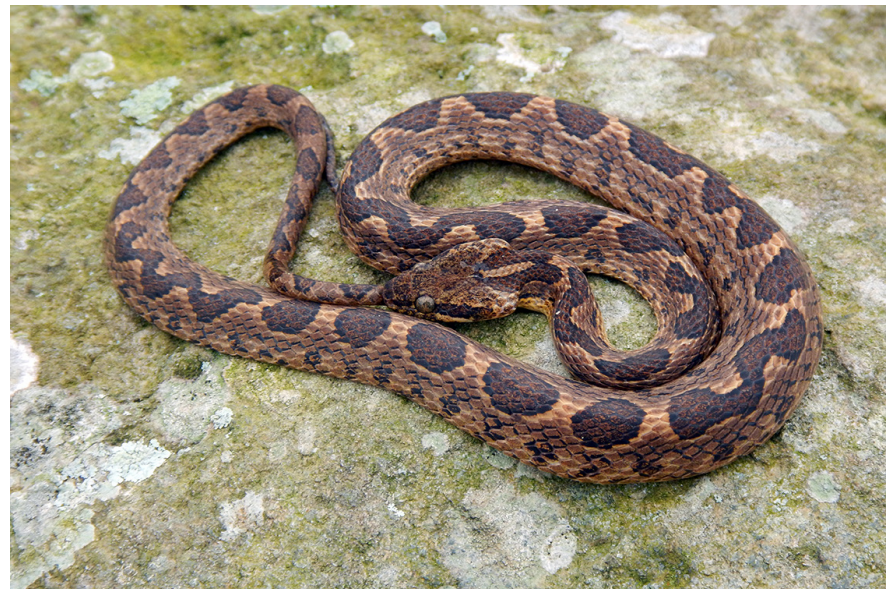

Fig 32. Leptodeira ashmeadi from Cerro Copey, Isla Margarita, Nueva Esparta, Venezuela. Photograph by Gilson Rivas.

However, genetic distance is not the only criterion for species diagnosis; I therefore consider (as did Savage 2002 and Solórzano 2004) that this species is valid due to its distinctive morphology, coloration, and adaptation to a unique habitat (mangroves).

\section{Leptodeira rhombifera Günther 1872}

This taxon was originally described from the Río Chisoy near Cubulco, Guatemala, and this name should be applied to the former $L$. annulata of Costa Rica, as well as Panama, Nicaragua, El Salvador (Fig. 34), Honduras (Fig. 35), Guatemala, and southern Mexico. In Costa Rica, the distribution is essentially restricted to the dry forests of the northwestern part of the country (Figs. 36 \& 37). However, confusion remains regarding the southern Pacific and the Caribbean versants, where $L$. ornata is prevalent. A few reports document "L. annulata" from the entire southwestern region, the entire Caribbean versant, and Panama, where it has been found at least as far east as Chepo, Panama Province (Fig. 38). The distribution in Panama is not well defined (Köhler 2003). During a period of seven years, I saw hundreds of $L$. ornata

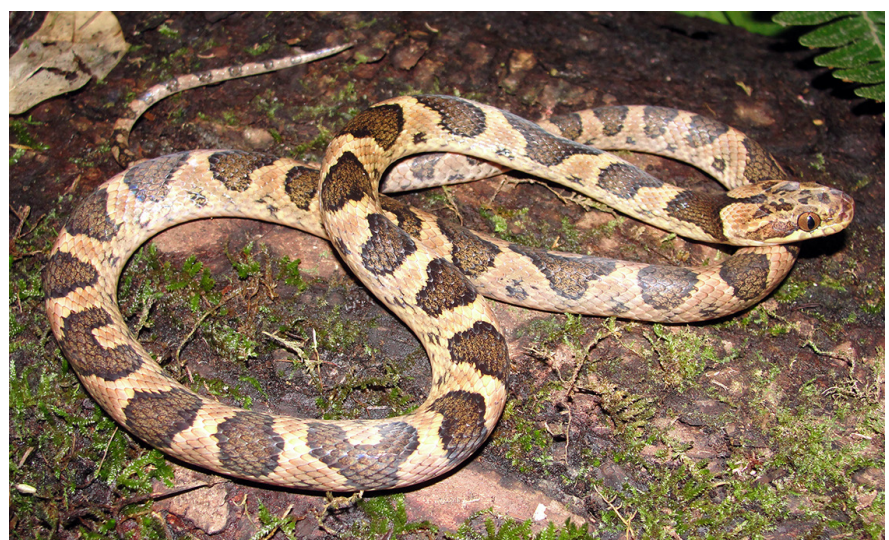

Fig 35. Leptodeira rhombifera from Jicatuyo, Los Llanitos, Santa Bárbara, Honduras. Photograph by Mario Espinal. 


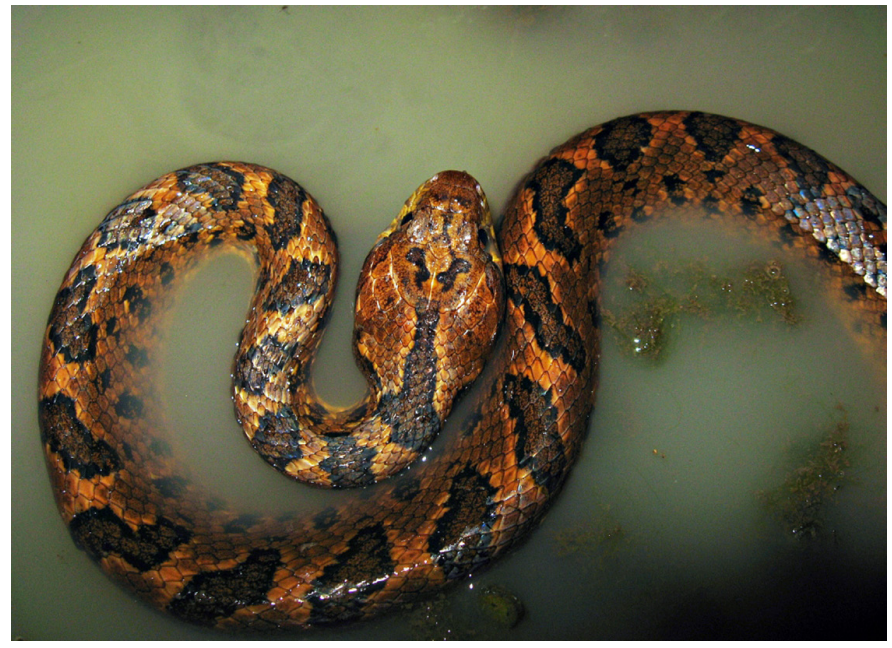

Fig 36. Leptodeira rhombifera from Parque Nacional Santa Rosa, Guanacaste, Costa Rica. Photograph by Juan Abarca.

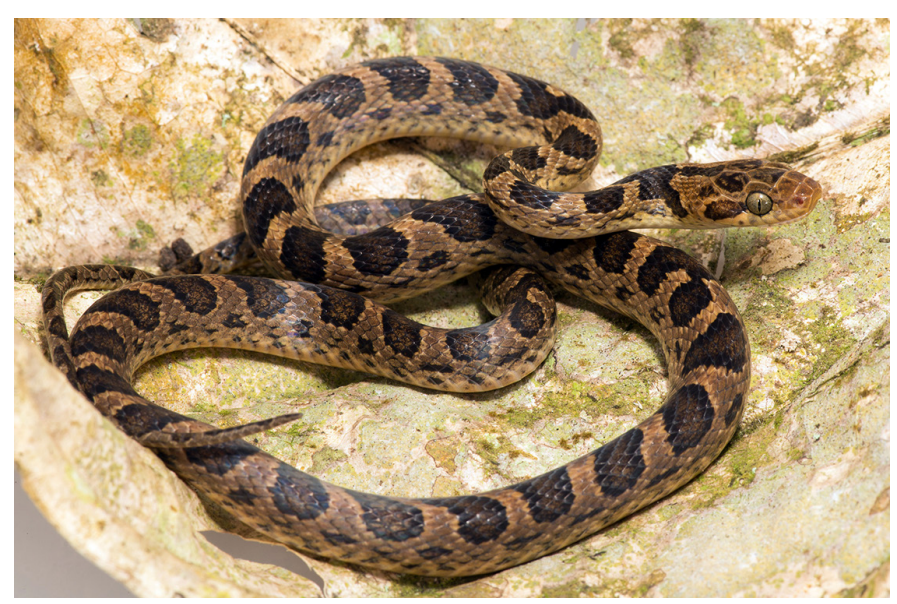

Fig 38. Leptodeira rhombifera from Chepo, Panama, Panama. Photograph by Twan Leenders.

in San Josecito de Uvita (rainforest at $300 \mathrm{~m}$ asl), Puntarenas, Costa Rica, and I recently saw different photographs of at least five individuals, one from the beach at Matapalo, Puntarenas, three from Uvita (Fig. 39), and another from La Mona, Golfito. Leptodeira rhombifera is sister to L. maculata (including $L$. a. cussiliris) and has L. rubricata nested basally; the whole clade is nested with L. polysticta (Daza et al. 2009), from which it differs substantially in pattern and shape.

\section{Leptodeira maculata (Hallowell 1861)}

Originally described in error as being from Tahiti, Duellman $(1958,1966)$ accurately restricted the type locality to Manzanillo, Colima, Mexico. The type locality of $L$. annulata cussiliris is Rancho Poso Rio, $6 \mathrm{~km}$ south of Tehuantepec, Oaxaca, Mexico (Duellman 1958). This taxon appears to be in the same clade as L. maculata, of which the latter is a senior synonym (contrary to Daza et al. 2009, who synonymized $L$. maculata with L. annulata cussiliris). Duellman (1958) had recognized the overall similarity of these two taxa, except for

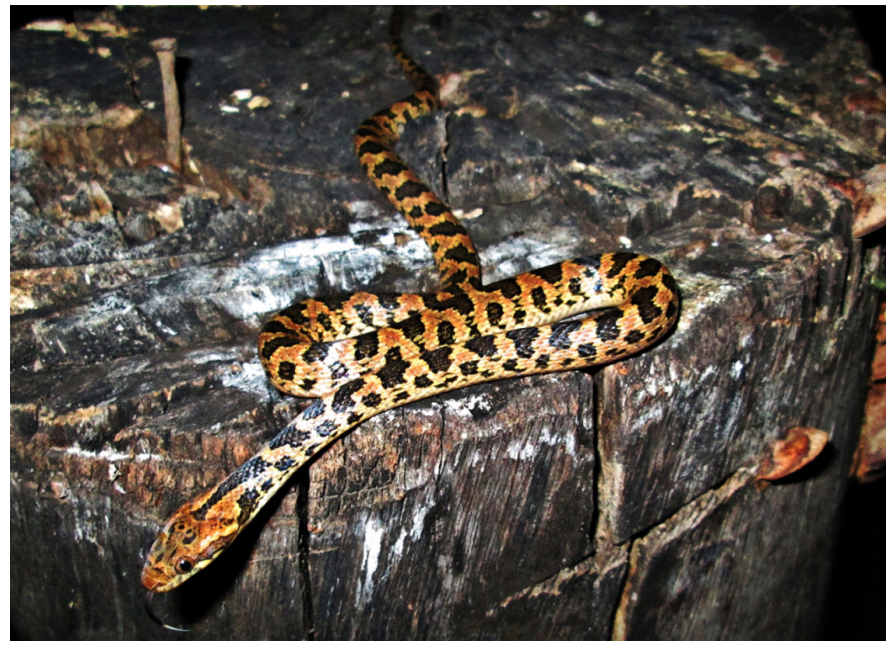

Fig 37. Leptodeira rhombifera from Barreal de Heredia, Heredia, Costa Rica. Photograph by Juan Abarca.

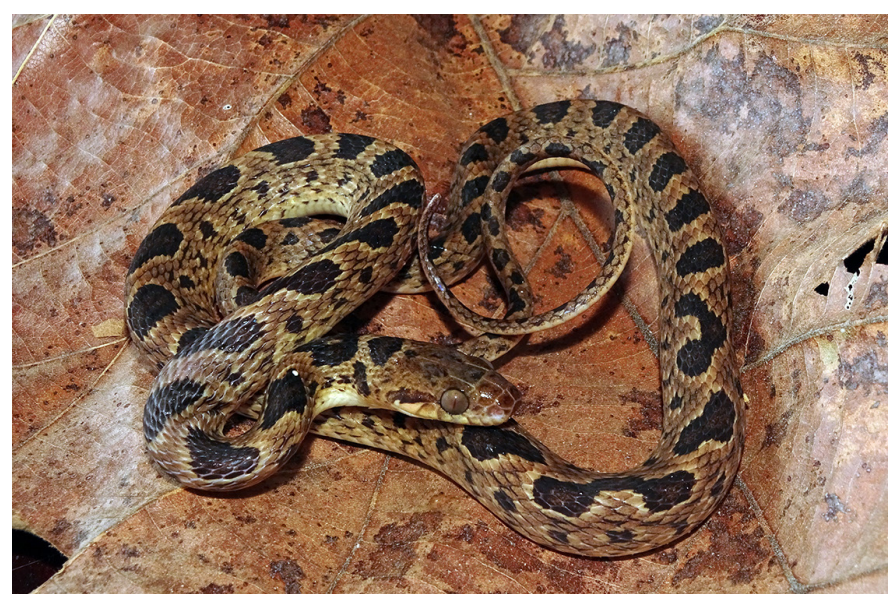

Fig 39. Leptodeira rhombifera from Uvita de Osa, Puntarenas, Costa Rica. Photograph by César L. Barrio-Amorós.

a gradient in the number of blotches. In the Pacific versant, L. maculata is known to occur in the lowlands and adjacent slopes of the Sierra Madre Occidental from southern Sinaloa to the Río Balsas, inland through the Balsas Basin in Michoacán and Guerrero to elevations of 2,000 m asl; on the Gulf of Mexico/Caribbean versant, the species ranges from southern Tamaulipas to the Isthmus of Tehuantepec and westward to the coasts of Chiapas and Oaxaca (Figs. 40 $\& 41)$.

\section{Other Species of Leptodeira}

The remaining species of Leptodeira are not part of the $L$. annulata-septentrionalis complex (Fig. 3 of Daza et al. 2009). Mexico seems the likely center of speciation for the genus, based on the greatest number of species (Table 2) and presence of the most basal taxa (Duellman 1958; Daza et al. 2009; Heimes 2016). Descriptions and distribution maps of Mexican species are in Heimes (2016). 


\section{Leptodeira nigrofasciata Günther 1868}

The most basal form in the genus is L. nigrofasciata (type locality: Nicaragua; Figs. $42 \& 43$ ); it is the sister taxon to all other species of Leptodeira. Mulcahy's (2007) maximum parsimony

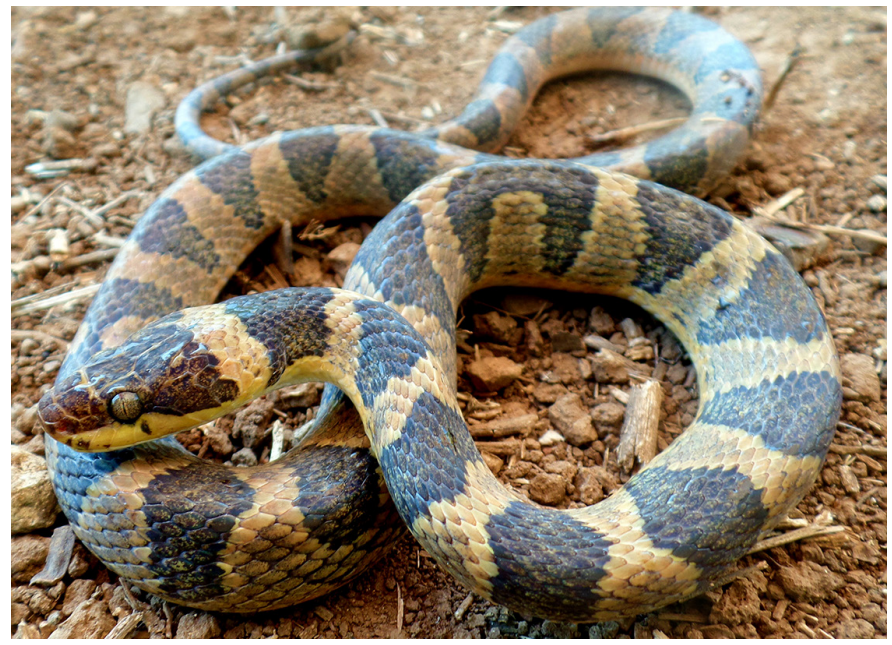

Fig. 40. Leptodeira maculata from Nayarit, Mexico. Photograph by Jesús Loc Barragán.

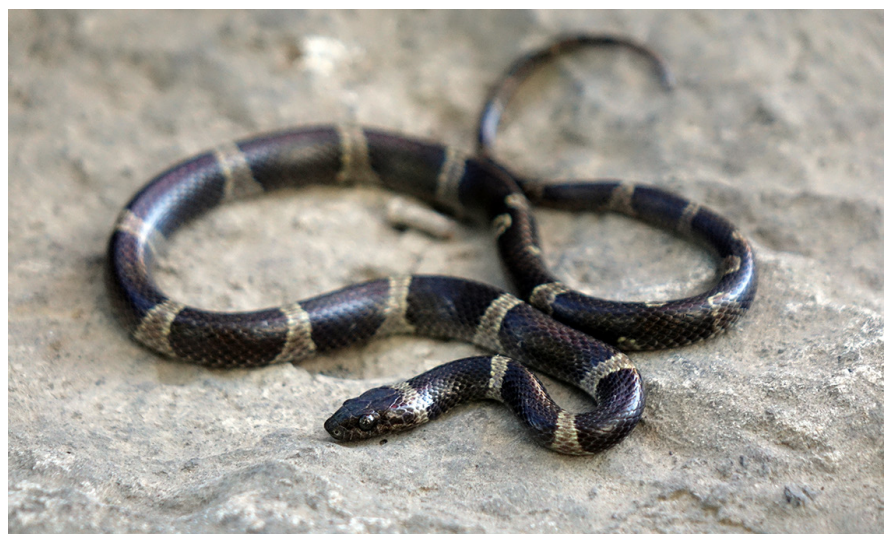

Fig. 42. Leptodeira nigrofasciata from Parque Nacional Santa Rosa, Guanacaste, Costa Rica. Photograph by César L. Barrio-Amorós.

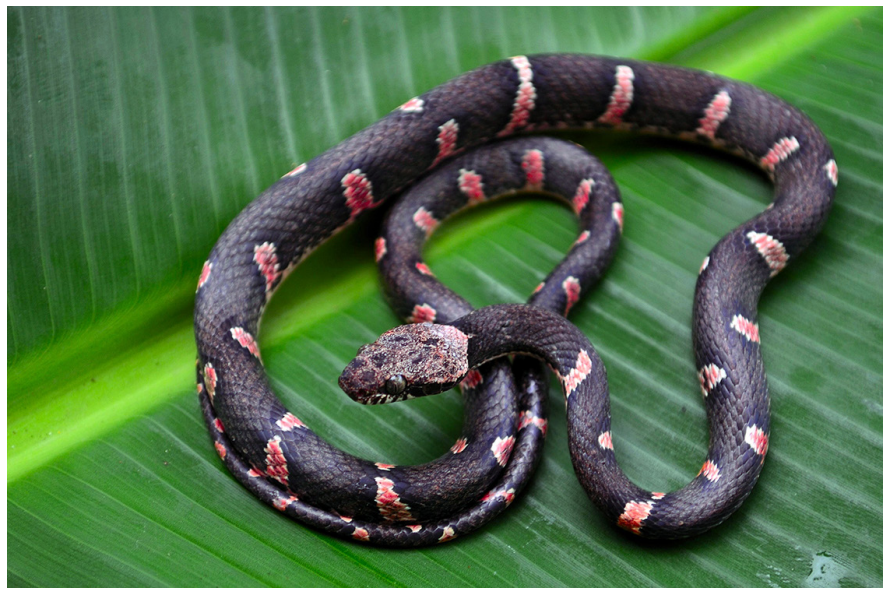

Fig. 44. Leptodeira frenata frenata from La Mancha, Veracruz, Mexico. Photograph by Juan Manuel González Villa. phylogeny of dipsadines shows L. nigrofasciata nested with Imantodes inornatus and basal to Imantodes and Leptodeira. The phylogenetic tree in Pyron's et al. (2013) shows a similar arrangement. However, Mulcahy (2007) did suggest that his

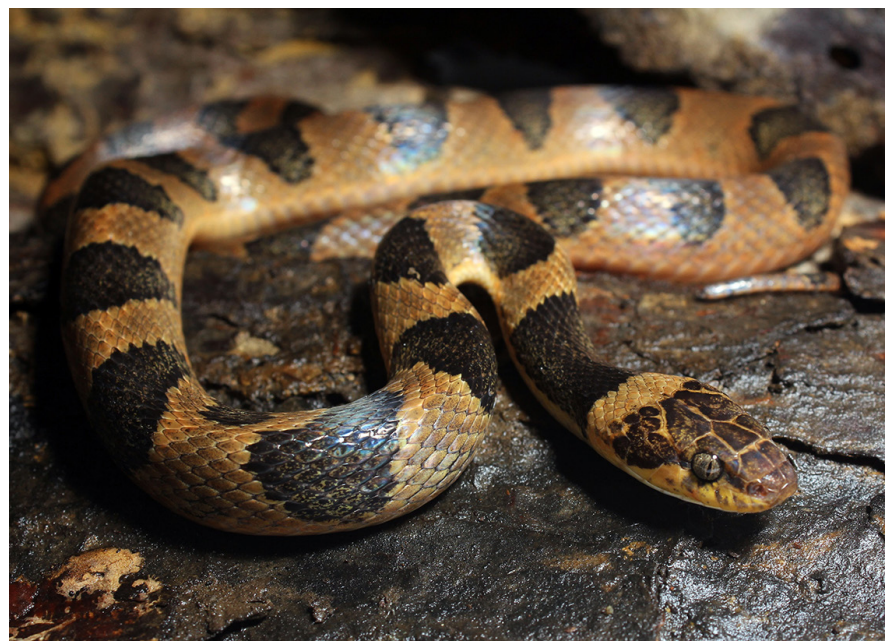

Fig. 41. Leptodeira maculata from Nayarit, Mexico. Photograph by Jesús Loc Barragán.

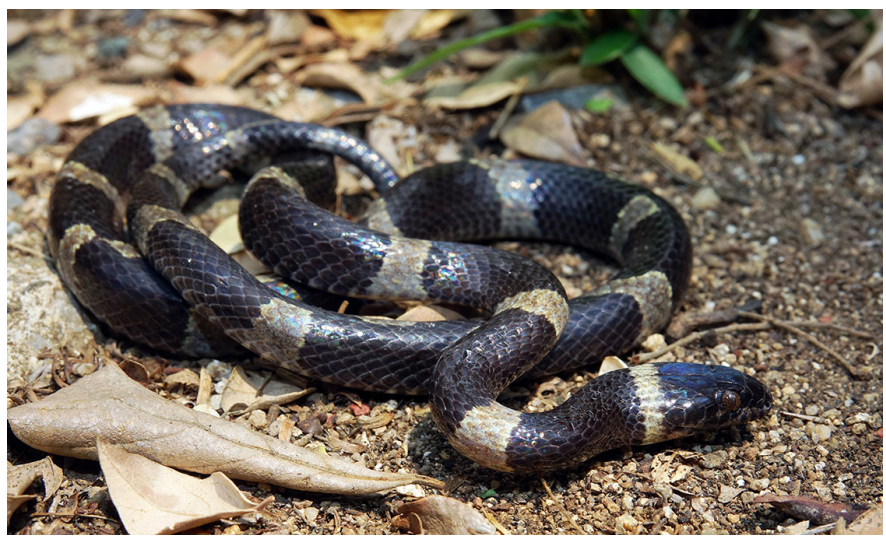

Fig. 43. Leptodeira nigrofasciata from Zacapa, Guatemala. Photograph by César L. Barrio-Amorós.

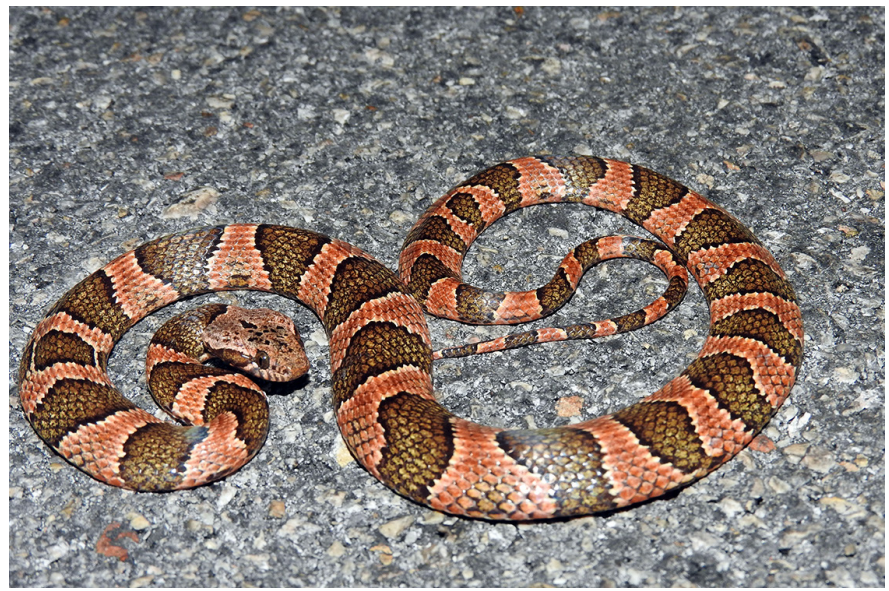

Fig. 45. Leptodeira frenata yucatanensis from Mérida, Yucatán, Mexico. Photograph by Jonatan Rizieri Avilés. 


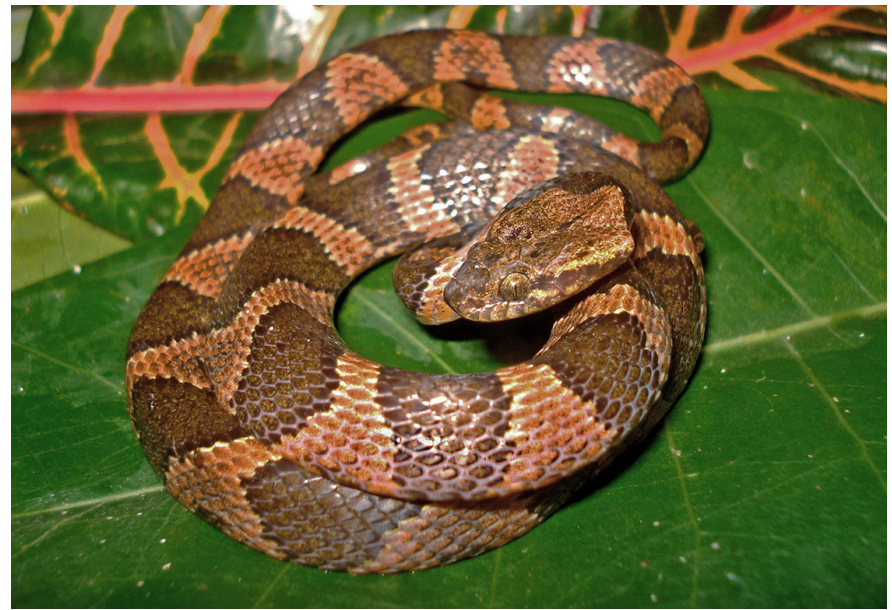

Fig. 46. Leptodeira frenata malleisi from Cozumel, Quintana Roo, Mexico. Photograph by Carlos Pavón.

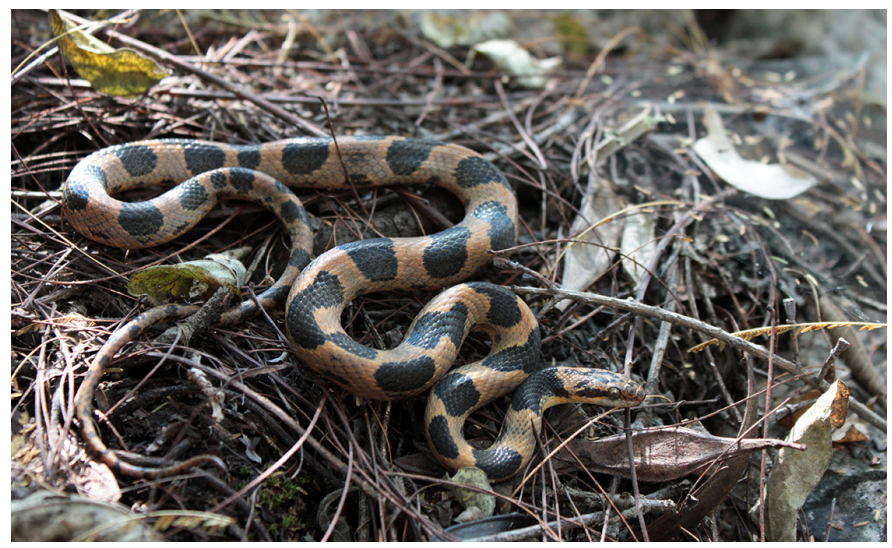

Fig. 48. Leptodeira splendida splendida from San Andrés de la Cal, Morelos, Mexico. Photograph by Samuel Arechaga.

results could be an artifact. His maximum likelihood analysis, however, is most similar to the tree in Daza et al. (2009); therefore, I have more confidence in that model.

\section{Leptodeira frenata (Cope 1886)}

Leptodeira frenata was described as Sibon frenatum by Cope (1886), for which the type locality is Jalapa, Veracruz, Mexico (Fig. 44). One year later, Cope (1887) described Sibon annulatum yucatanensis, with a type locality of Chichén Itzá, Yucatán, Mexico (Fig. 45), which is now recognized as L. frenata yucatanensis. Dunn and Stuart (1935) described the subspecies L.f. malleisi (Fig. 46), with a type locality of Tuxpeña, Campeche, Mexico. The nominal subspecies ranges from central Veracruz toward Tabasco in Mexico. Leptodeira f. malleisi is more widely distributed and occurs throughout the southern and eastern parts of the Yucatán Peninsula, including the island of Cozumel. Leptodeira f. yucatanensis is limited to the northwestern Yucatán Peninsula. Unfortunately, neither Mulcahy (2007) nor Daza et al. (2009) mentioned which subspecies of $L$. frenata they tested; their same sam-

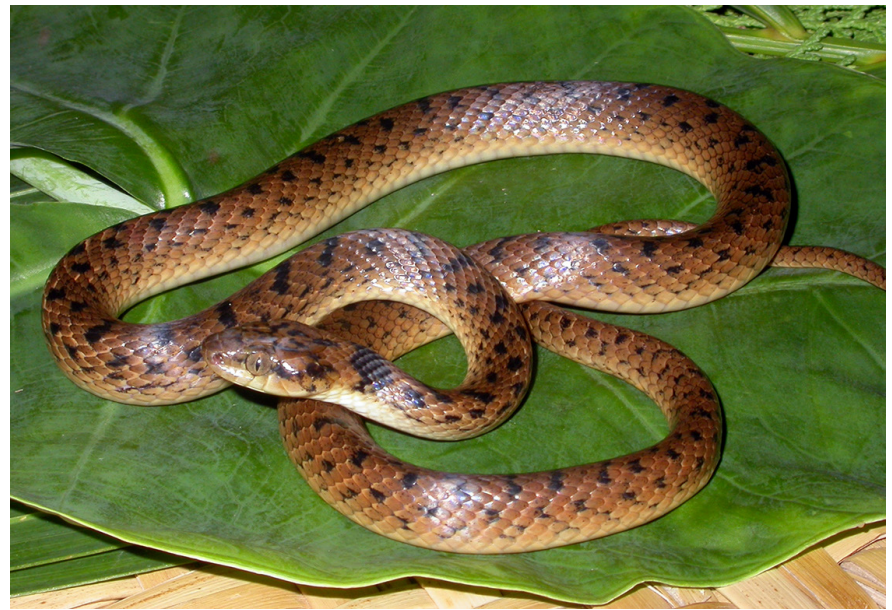

Fig. 47. Leptodeira punctata from Teacapán, Sinaloa, Mexico. Photograph by Chris Grünwald/HERP MX.

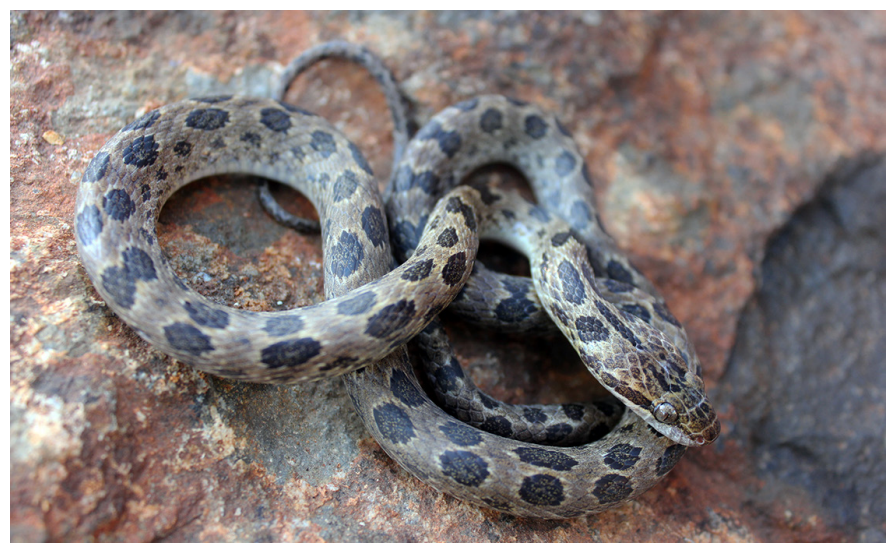

Fig. 49. Leptodeira splendida bressoni from San Blas, Nayarit, Mexico. Photograph by Jesús Loc Barragán.

ples are from Campeche (an area that includes the distribution of L. frenata malleisi) and from Guerrero (probably in error, as Guerrero is outside the distribution of L. frenata; see Duellman 1958). Genetic analyses are needed to assess the validity of these subspecies.

\section{Leptodeira punctata (Peters 1867)}

The type locality of $L$. punctata is Mazatlán, Sinaloa, Mexico. This species occurs in western Mexico, from northern Sinaloa to northwestern Jalisco to elevations of $1,600 \mathrm{~m}$ asl (Duellman 1958; Heimes 2016). This is the only species in the genus with small dark scattered dots instead of bands or blotches on the dorsum (Fig. 47).

\section{Leptodeira splendida Günther 1895}

The type locality of L. splendida is Izucar de Matamoras, Puebla, Mexico. This species has three currently recognized subspecies: the nominal L. s. splendida (Fig. 48) from Morelos, Guerrero, and Puebla, Mexico, at elevations to $1,750 \mathrm{~m}$ asl; L. s. bressoni Taylor 1938 (type locality Uruapán, Michoacán, 


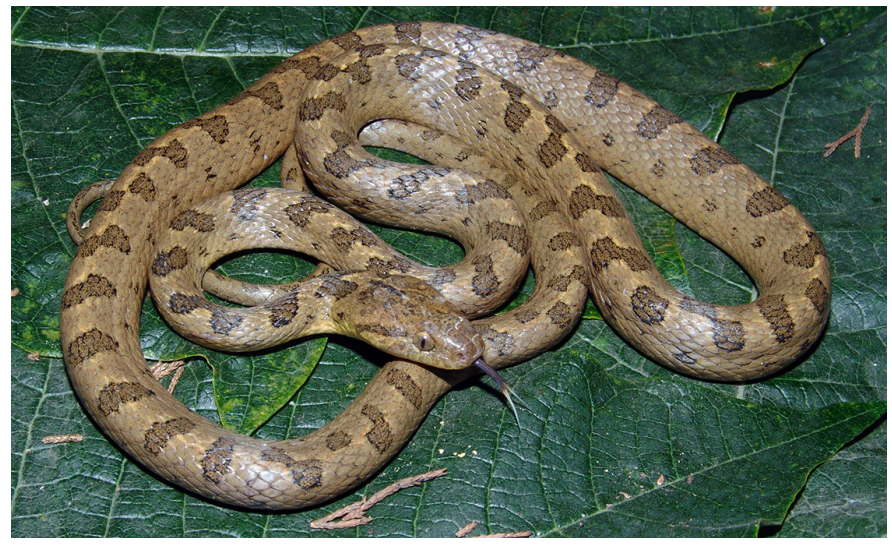

Fig. 50. Leptodeira splendida ephippiata from Espinazo del Diablo, Durango, Mexico. Photograph by Chris Grünwald/HERP MX.

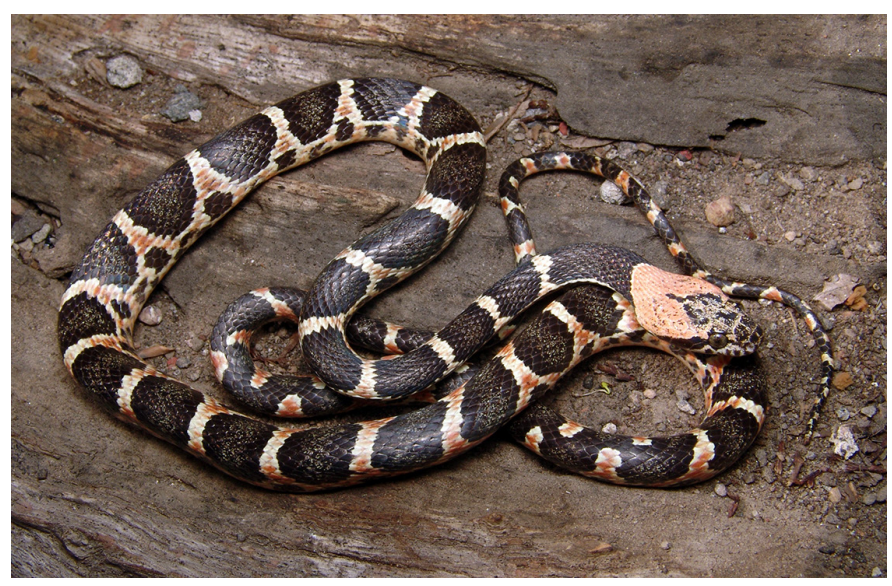

Fig. 52. Leptodeira uribei from Minatitlán, Colima, Mexico. Photograph by Jason Jones/HERP MX.

Mexico; Fig. 49), from Colima, Jalisco, and Michoacán, Mexico; and L. s. ephippiata Smith and Tanner 1944 (type locality Los Álamos, Sonora, Mexico; Figs. 50 \& 51) from northwestern Sonora to Sinaloa and Durango. The last subspecies was not examined by Mulcahy (2007) or Daza et al. (2009) and is not mentioned by either. A genetic analysis is needed to assess the validity of at least the latter subspecies.

Leptodeira uribei (Bautista and Smith 1992)

This species was described as Pseudoleptodeira uribei until, based on molecular data, it was referred to Leptodeira by Reyes-Velasco and Mulcahy (2010). Leptodeira uribei occurs along the Pacific coast of Oaxaca to Jalisco (Figs. 52 \& 53).

\section{Acknowledgements}

I thank all of the friends and colleagues with whom I have spent much time discussing the taxonomy of Leptodeira and many other reptilian taxa, but especially Quetzal Dwyer, Alejandro Solórzano, Roel de Plecker, Bill Lamar, Mahmod Sasa, Juan Pablo Diasparra, Juan Abarca, Jaime Culebras, Darwin Núñez, Kevin Venegas, Pablo Venegas, Ray Morgan,

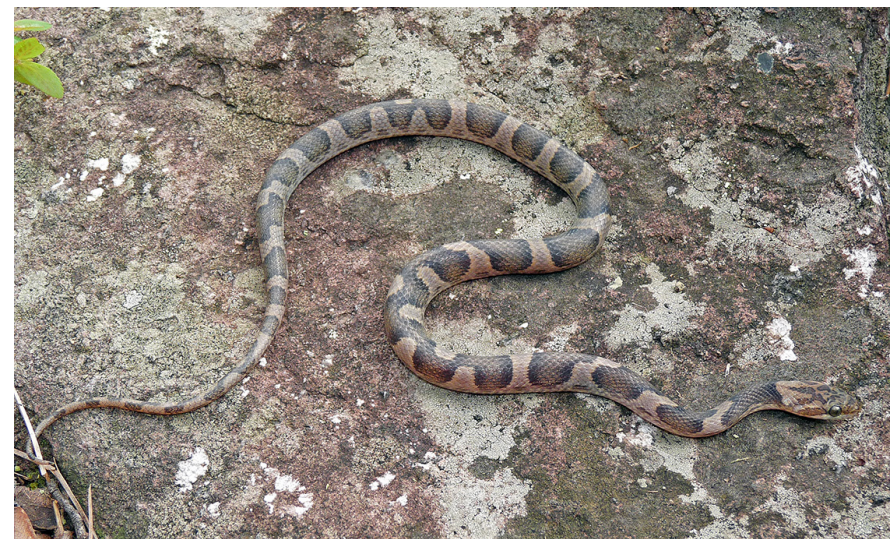

Fig. 51. Leptodeira splendida ephippiata from Yecora, Sonora, Mexico. Photograph by Mike Pingleton.

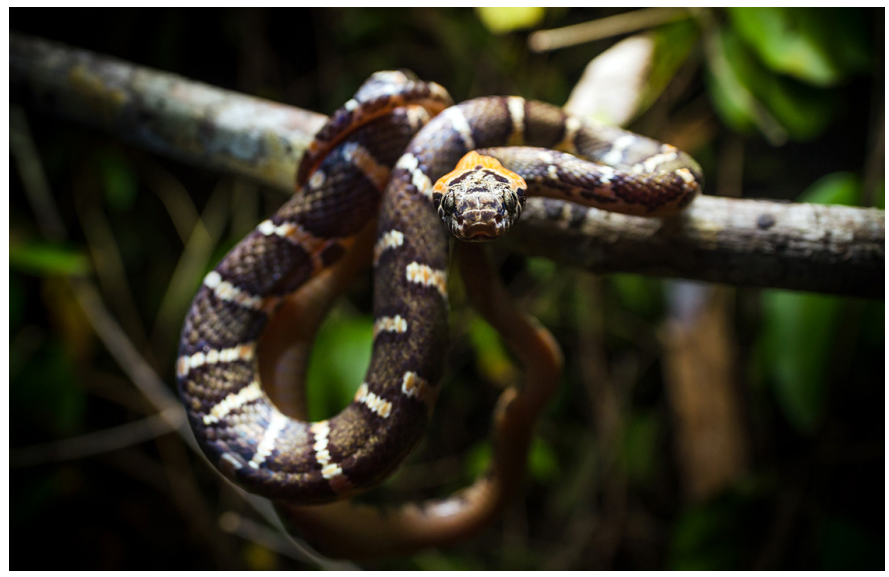

Fig. 53. Leptodeira uribei from Chamela, Jalisco, Mexico. Photograph by Juan Manuel González Villa.

and Milton Salazar. Juan Daza graciously provided the phylogenetic tree used to illustrate the relationships presented in this paper. Gerardo Chaves "Cachi" allowed access to the herpetological collection of the Universidad de Costa Rica to examine specimens.

I also am deeply thankful to those who generously provided photographs for this article: Juan Manuel GonzálezVilla, Jesús Loc-Barragán, Pedro Nahuat, Luis Díaz-Gamboa, Luis Alejandro Rodríguez, Jonatan Rizieri-Avilés, Orlando Garcés, Pedro Uriarte, Clint Guadiana, Louis Porras, Ton Dubislav, Danilo Krause, Omar Machado, Mario Espinal, Josué Ramos Galdamez, Twan Leenders, Juan Abarca, Milton Salazar, Fabio Maffei, Saymon de Albuquerque, Marco Antonio de Freitas, Gilson Rivas, Sebastian Valverde, Iván Ahumada Carrillo, Jason Jones, Chris Grünwald, Mike Pingleton, Elson Meneses Pelayo, Fernando Rojas-Runjaic, Samuel Arechaga, and Carlos Pavón.

\section{Literature Cited}

Bautista, A.R. and H.M. Smith. 1992. A new chromospecies of snake (Pseudoleptodeira) from México. Bulletin of the Maryland Herpetological Society 28: 83-98. 
Campbell, J.A. 1998. Amphibians and Reptiles of Northern Guatemala, the Yucatán, and Belize. University of Oklahoma Press, Norman.

Daza, J.M., E.N. Smith, V.P. Páez, and C.L. Parkinson. 2009. Complex evolution in the Neotropics: The origin and diversification of the widespread genus Leptodeira (Serpentes: Colubridae). Molecular Phylogenetics and Evolution 53: 653-667.

Duellman, W.E. 1958. A monographic study of the colubrid snake genus Leptodeira. Bulletin of the American Museum of Natural History 114: 1-152.

Duellman, W.E. 1966. Remarks on the systematic status of certain Mexican snakes of the genus Leptodeira. Herpetologica 22: 97-106.

Duellman, W.E. and J.E. Werler. 1955. Variation and relationships of the colubrid snake Leptodeira frenata. Occasional Papers of the Museum of Zoology, University of Michigan 570: 1-9.

Hallowell, E. 1845. Description of reptiles from South America, supposed to be new. Proceedings of the Academy of Natural Sciences of Philadelphia 2: 241-250.

Heimes, P. 2016. Herpetofauna Mexicana Vol. I. Snakes of México. Edition Chimaira, Frankfurt am Main, Germany.

Koch, C., P.J. Venegas, R. Santa Cruz, and W. Böhme. 2018. Annotated checklist and key to the species of amphibians and reptiles inhabiting the northern Peruvian dry forest along the Andean valley of the Marañón River and its tributaries. Zootaxa 4385: 1-101.

Köhler, G. 2003. Reptiles of Central America. Herpeton Verlag, Offenbach, Germany.

Linnaeus, C. 1758. Systema nature per regna tria natura, secundum classes, ordines, genera, species, cum characteribus, differentiis, synonymis, locis. Tomus I. Editio decima, reformata. Laurentii Salvii, Holmix.

Mijares-Urrutia, A., A.L. Markezich, and R.A. Arends. 1995. Hallazgo de Leptodeira bakeri Ruthven (Serpentes: Colubridae) en la Peninsula de Paraguaná, moroeste de Venezuela: con comentarios diagnósticos y biológicos. Caribbean Journal of Science 31: 77-82.

Mulcahy, D.G. 2007. Molecular systematics of Neotropical cat-eyed snakes: A test of the monophyly of Leptodeirini (Colubridae: Dipsadinae) with implications for character evolution and biogeography. Biological Journal of the Linnean Society 92: 483-500.

Mulcahy, D.G., T.H. Beckstead and J.W. Sites, Jr. 2011. Molecular systematics of the Leptodeirini (Colubroidea: Dipsadidae) revisited: Species-tree analyses and multi-locus data. Copeia 2011: 407-417.

Natera Mumaw, M., L.F. Esqueda González, and M. Castelaín Fernández. 2015. Atlas Serpientes de Venezuela. Una visión actual de su diversidad. Santiago, Chile.

Pérez-Santos, C. 1999. Serpientes de Panamá. Volume 2 of BIOSFERA / Publicaciones del Comité Español del Programa MaB y de la Red IberoMaB de la UNESCO, Sevilla, España.

Pyron, A.R., F.T. Burbrink, and J.J. Wiens. 2013. A phylogeny and revised classification of Squamata, including 4161 species of lizards and snakes. BMC Evolutionary Biology 2013: 1-53.

Reyes-Velasco, J. and D.G. Mulcahy. 2010. Additional taxonomic remarks on the genus Pseudoleptodeira (Serpentes: Colubridae) and the phylogenetic placement of "P. uribei." Herpetologica 66: 99-110.

Ruthven, A.G. 1936. Leptodeira bakeri, new species. Occasional Papers of the Museum of Zoology, University of Michigan 330: 1-2.

Savage, J.M. 2002. The Amphibians and Reptiles of Costa Rica: A Herpetofauna Between Two Continents, Between Two Seas. University of Chicago Press, Chicago, Illinois.

Schmidt, K.P. and W.F. Walker, Jr. 1943. Snakes of the Peruvian Coastal Region. Zoological Series of Field Museum of Natural History 24: 297-327.

Scrocchi, G.J. 1980 Nuevos datos sobre Leptodeira annulata pulchriceps Duellman (Ophidia: Colubridae) en Argentina. Acta Zoologica Lilloana 36: 149-151.

Solórzano, A. 2004. Serpientes de Costa Rica. Instituto Nacional de Bioversidad, Santo Domingo de Heredia, Costa Rica.

Uetz, P., P. Freed, and J. Hošek (eds.). 2018. The Reptile Database (http://www. reptile-database.org). 